\title{
Article \\ The Effect of Biochar-Based Organic Amendments on the Structure of Soil Bacterial Community and Yield of Maize (Zea mays L.)
}

\author{
Agnieszka Wolna-Maruwka ${ }^{1, *}\left(\mathbb{C}\right.$, Tomasz Piechota ${ }^{2}\left(\mathbb{D}\right.$, Alicja Niewiadomska ${ }^{1}\left(\mathbb{D}\right.$, Adam Kamiński $^{3}$, \\ Dariusz Kayzer ${ }^{4}$, Aleksandra Grzyb ${ }^{1}$ and Agnieszka A. Pilarska ${ }^{5}$
}

check for

updates

Citation: Wolna-Maruwka, A.;

Piechota, T.; Niewiadomska, A.;

Kamiński, A.; Kayzer, D.; Grzyb, A.;

Pilarska, A.A. The Effect of

Biochar-Based Organic Amendments

on the Structure of Soil Bacterial

Community and Yield of Maize

(Zea mays L.). Agronomy 2021, 11, 1286.

https: / / doi.org/10.3390/

agronomy 11071286

Academic Editors: Anna Gałązka,

Agnieszka Wolińska and Vanessa

Alvarez Lopez

Received: 2 June 2021

Accepted: 22 June 2021

Published: 24 June 2021

Publisher's Note: MDPI stays neutral with regard to jurisdictional claims in published maps and institutional affiliations.

Copyright: (c) 2021 by the authors. Licensee MDPI, Basel, Switzerland. This article is an open access article distributed under the terms and conditions of the Creative Commons Attribution (CC BY) license (https:// creativecommons.org/licenses/by/ $4.0 /)$.
1 Department of General and Environmental Microbiology, Poznań University of Life Sciences, Szydłowska 50, 60-656 Poznań, Poland; alicja.niewiadomska@up.poznan.pl (A.N.); aleksandra.grzyb@up.poznan.pl (A.G.)

2 Department of Agronomy, Poznań University of Life Sciences, Dojazd 11, 60-656 Poznań, Poland; tomasz.piechota@up.poznan.pl

3 International Chemical Company S.A., Łużycka 50, 66-200 Świebodzin, Poland; a.kaminski@iccsa.pl

4 Department of Mathematical and Statistical Methods, Poznań University of Life Sciences, Wojska Polskiego 28, 60-637 Poznań, Poland; dariusz.kayzer@up.poznan.pl

5 Department of Plant-Derived Food Technology, Poznań University of Life Sciences, Wojska Polskiego 31, 60-624 Poznań, Poland; agnieszka.pilarska@up.poznan.pl

* Correspondence: amaruwka@up.poznan.pl; Tel.: +48-618-466-724

\begin{abstract}
The taxonomic and functional diversity of bacteria in seven different experimental variants applied to soil under a maize plantation was determined by means of next-generation sequencing and biochemical methods. The aim of the study was to discover differences in the structure of bacteria and the level of soil enzymatic activity (BIF-biochemical index of fertility) after the application of a biofertiliser made of lignocellulosic substrate and biochar containing various microorganisms (algae, mycorrhizal fungi of the Glomus genus or the consortium of Bacillus sp. bacteria). The chemical composition and yield of crops was a measurable indicator of the effectiveness of the fertilisers. The biofertilisers influenced both the structure and the percentage share of individual bacterial operational taxonomic units (OTU). The cultivation of maize also modified qualitative and quantitative changes in the soil bacterial microbiome. A canonical variate analysis (CVA) showed that the soil $\mathrm{pH}$ exhibited a minimal positive correlation with the soil enzymatic activity and selected plant parameters, with the exception of the biofertiliser variant with arbuscular mycorrhiza (AM). Moreover, the AM biofertiliser significantly increased the BIF value, the yield of maize seeds and the starch content in the plants. The comprehensive nature of the research allowed for a deepening and systematization of the existing knowledge on the influence of biochar with the addition of selected microorganisms on the biochemical parameters of the soil and the bacterial biodiversity of the soil environment. Additionally, the inclusion of the chemical, sanitary composition and yield of maize in the research brought a measurable view of the changes taking place in the soil and plant environment under the influence of the discussed factor. Apart from the agronomic aspect (integrated crop cultivation-Directive 2009/128/EC) of our study, it was also closely related to environmental protection, as it proved that biochar-based biofertilisers could be an alternative to mineral fertilisation.
\end{abstract}

Keywords: biofertiliser; bacterial biodiversity; biochemical index of fertility; crop yield

\section{Introduction}

Over-intensive farming based on a simplified crop structure and intensive tillage as well as the excessive use of mineral fertilisers and chemical crop protection products in order to obtain the highest yield disturb the biological balance in soil. In consequence, the transformation of nutrients is disturbed, the immunity of pathogens and pests increases, 
while surface and ground waters become polluted [1,2]. Nowadays, expectations concerning agriculture are not limited to crop production only. Today agricultural production must consider another aspect-how to minimise environmental hazards through the effective use of means of production, including nutrients $(\mathrm{K}, \mathrm{Mg}, \mathrm{Na}, \mathrm{N}, \mathrm{P})$ supplied to plants with fertilisers $[3,4]$.

The problem of minimising environmental hazards can be solved by applying crop residue with biochar and beneficial microorganisms into soil [5]. According to Butterly et al. [6] and Whalen [7], crop residue increases the porosity of soil, improves its hydrological properties, and stimulates the activity of soil microorganisms. As a consequence, soil fertility improves, crop productivity increases and the loss of nutrients through their leaching from the substrate is prevented.

Biochar significantly influences the function of the soil ecosystem. The mechanisms of its action are very similar to those caused by the application of plant residue. Biochar prevents the leaching of soil nutrients, reduces gas emissions, increases water capacity, and the absorption of organic and inorganic pollutants. Like plant residue, biochar is also a source of nutrients for microorganisms [8,9]. Due to the large surface area of biochar particles and the width of their pores they are an ideal habitat for the soil microbiome.

A literature review shows that the specific surface area (SSA) is one of the most important features of biochar, influencing the retention of nutrients, its adsorption capacity and the activity of soil microorganisms. Moreover, the SSA value of biochar is related to several other properties, such as: CEC (Cation Exchange Capacity) and WHC (Water Holding Capacity), therefore it is an important parameter determining the use of biochar in modern agriculture [4]. The main factor influencing the value of the SSA is the pyrolysis temperature and the type of substrate. It has been shown that higher pyrolysis temperatures release volatile substances and create more pores in the biocarbon. The pyrolysis of plant waste, e.g., cotton seed hulls, leads to biochar with a low SSA value $\left(4.7 \mathrm{~m}^{2} / \mathrm{g}\right)$, and that of animal manure to a higher SSA value $\left(13 \mathrm{~m}^{2} / \mathrm{g}\right)[10,11]$.

As results from scientific publications show, biochar alters the physicochemical properties of soil and, in consequence, it may significantly change the activity and structure of soil microorganisms, thus affecting interactions between plants and microorganisms and lead to an increased plant yield [12,13].

According to Blackwell et al. [14], a small but concentrated dose of organic matter enriched with biochar may significantly change the local soil conditions in the vicinity of maize seedlings. If there are favourable conditions for microbiological components applied into soil with this carrier, they may intensively colonise the soil and roots of crops, thus improving their yield.

A wide range of microorganisms promote the growth and development of plants. These include mycorrhizal fungi of the Glomus genus, which can be used as a high ecological utility biofertiliser when combined with plant waste [15]. These microorganisms increase the root absorption area and thus ensure a better supply of water to plants. They also produce $B$ vitamins and substances which stimulate the growth of plants, and increase their ability to take up minerals such as $\mathrm{P}, \mathrm{Zn}, \mathrm{Cu}, \mathrm{S}, \mathrm{Co}, \mathrm{K}, \mathrm{Fe}, \mathrm{Mg}$, and $\mathrm{N}$. Mycorrhizal fungi also affect plants' resistance to biotic stresses, such as pathogens, and abiotic stresses, e.g., drought, too high or low temperatures, heavy metals and other toxic substances in the substrate [16,17]. Mycorrhizal fungi have been proven not only to support plant growth and health, but also to improve the soil structure and bioactivity in the root zone, which may limit the processes of water and wind erosion [18].

Currently, biopreparations based on Bacillus sp. bacteria are very popular. Biotechnology companies use these microorganisms to promote plant growth because they proliferate rapidly and have the ability to overproduce and secrete various active extracellular proteins, including those with a phytopathogenic effect. Bacillus sp. strains received a GRAS (Generally Recognized as Safe) designation from the United States Food and Drug Administration to prove their lack of toxicity or pathogenicity. These microorganisms affect plants both directly and indirectly. Their indirect stimulation consists of limiting or pre- 
venting the harmful effects of phytopathogenic organisms such as Fusarium oxysporum, Fusarium vericillioides, Fusarium solani, Fusarium ciceri, Phytophtora capisici, Rhizoctonia solani, Rhizoctonia batatida, Sclerotinia sclerotium, and Colletotrichum musae.

Bacillus sp. bacteria control pathogens by producing antibiotics and siderophores, which chelate iron and thus prevent pathogenic microorganisms from taking it up from the substrate. These bacteria also compete for ecological niches and nutrients and they synthesise lytic enzymes, which break down the cell wall of pathogenic fungi [19]. Bacillus sp. bacteria directly stimulate plant growth by synthesising phytohormones such as auxins, gibberellins, and cytokinins [20].

Selected species of Bacillus bacteria are classified as plant growth-promoting bacteria (PGPR). Their presence in the rhizosphere leads to a state of induced systemic resistance (ISR), in which plants exhibit increased, non-specific resistance to all types of pathogens and pests: viruses, bacteria, fungi, nematodes, and insects. Bacillus sp. bacteria promote plants' faster and stronger defensive reactions when they are attacked by pathogens [21]. Bacteria of the Bacillus genus have a well-developed enzyme apparatus, which they use to mineralise organic matter in the substrate and thus increase the availability of minerals for plants. They are also capable of producing organic acids, which dissolve unavailable forms of phosphorus in the substrate, mainly aluminium and iron phosphates, found in acidic soils, and calcium phosphate, found in highly alkaline soils [22].

There are also commercially available biopreparations based on algae, which have a high fertilising potential due to their high content of macronutrients. Furthermore, thanks to their high content of phytohormones, they accelerate seed germination, strengthen plants' roots, increase their vitality and stimulate their growth $[23,24]$. According to scientific publications, algae extracts improve the water capacity of soil and can inhibit the development of pathogens thanks to the antibacterial and antifungal substances they contain $[25,26]$. Like mycorrhizal fungi and beneficial microorganisms from the Bacillus genus, algae combined with processed plant mass seem to be an interesting alternative to mineral fertilisation.

The literature review shows that there are currently many studies on the influence of different origins of biochar on the formation of the microbial community of the soil, its impact on soil fertility, as well as the yield and chemical composition of crops [27,28]. However, there are few scientific reports on the simultaneous influence of biochar inoculated with microorganisms, in particular fungi of the Glomus genus, and algae, on both the microbiological and biochemical parameters of the soil, as well as the chemical composition, health and yield of maize, in particular in Polish climatic conditions [29-31]. Such a broad research problem regarding the influence of biochar with the addition of microorganisms on both selected soil and plant parameters is currently very topical, due to the introduction of an initiative called the 'Green Deal' at the end of 2019, which assumes a holistic and comprehensive approach to environmental protection and counteracting climate change. The European Commission published it on 20 May 2020 in the form of the European Biodiversity Strategy. According to the guidelines of this project, by 2030 a $20 \%$ reduction in the use of mineral fertilisers and a $50 \%$ reduction in the use of pesticides is expected, with the simultaneous balancing of their use with preparations containing biological active substances [32].

The aim of the study was to investigate how a biofertiliser composed of processed plant mass, biochar, and selected microorganisms influenced: (i) the biodiversity of the soil bacterial microbiome and soil enzymatic activity under a maize plantation, (ii) the yield of seeds and the chemical composition of plants, (iii) the health of plants.

\section{Materials and Methods}

\subsection{The Study Site}

In 2018 and 2019 a strict field experiment was conducted on a private farm located in the village of Glińsk, Świebodzin County, Poland ( $52^{\circ} 18^{\prime} 27.04^{\prime \prime}$ N $15^{\circ} 33^{\prime} 33.845^{\prime \prime}$ E), on soil classified as Albic Luvisols developed on loamy sands overlying loamy material. The study 
presents the results of microbiological and chemical investigations as well as measurements of the average yield of crops in the two years of the experiment. The soil had a low content of organic matter, a medium content of available forms of phosphorus, potassium, and magnesium, and a neutral $\mathrm{pH}$ (Table 1).

Table 1. Soil properties at the experimental site $(0-25 \mathrm{~cm})$.

\begin{tabular}{cc}
\hline Properties & Content \\
\hline Organic C $\left(\mathrm{g} \mathrm{kg}^{-1}\right)$ & 5.61 \\
Total $\mathrm{N}\left(\mathrm{g} \mathrm{kg}^{-1}\right)$ & 0.57 \\
$\mathrm{Ca}\left(\mathrm{g} \mathrm{kg}^{-1}\right)$ & 2.61 \\
$\mathrm{P}\left(\mathrm{mg} \mathrm{kg}^{-1}\right)$ & 50.8 \\
$\mathrm{~K}\left(\mathrm{mg} \mathrm{kg}^{-1}\right)$ & 11.85 \\
$\mathrm{Mg}\left(\mathrm{g} \mathrm{kg}^{-1}\right)$ & 31.01 \\
$\mathrm{pH} \mathrm{KCl}$ & 6.95 \\
\hline
\end{tabular}

Seeds of the Farmsaat $\mathrm{CH} 4$ maize cultivar were sown in rows at a site which had previously been a soybean plantation. The rows were spaced at $75 \mathrm{~cm}$ from each other. The sowing density was 80.000 plants per ha. In autumn, after the forecrop had been harvested, the soil was ploughed to a depth of about $30 \mathrm{~cm}$. In spring, the soil was prepared for sowing by means of a light cultivator and string rollers. On 9 May 2018 and 10 May 2019 seeds were sown to a depth of $5 \mathrm{~cm}$ with a Taarup seed drill equipped with a fertiliser applicator with a tined working element. The biofertilisers tested in the experiment were applied at planting, with the fertiliser applicator at a dose of $300 \mathrm{~kg} / \mathrm{ha}$, to a depth of $10 \mathrm{~cm}$, $5 \mathrm{~cm}$ away from the plant row. No mineral fertilisers were used so that the high supply of nutrients would not blur the effect of the tested products. At the phase of three maize leaves Elumis 105 OD herbicide (mesotrione $75 \mathrm{~g} \mathrm{~L}^{-1}+$ nicosulfuron $30 \mathrm{~g} \mathrm{~L}^{-1}$ ) was applied at a dose of $1.5 \mathrm{~L} \mathrm{ha}^{-1}$. Neither fungicides nor insecticides were applied to the plants.

The study was conducted in rain-fed conditions, which is typical practice in Poland. Average precipitation of the area is $534 \mathrm{~mm}$ and air temperature $8.0{ }^{\circ} \mathrm{C}$ but 2018 and 2019 were extremely hot and dry. Air temperature was 2.3 and $2.6^{\circ} \mathrm{C}$ higher, respectively, and precipitation 160 and $115 \mathrm{~mm}$ below average.

There were seven variants in the experiment, each in three replications $\left(30 \mathrm{~m}^{2}\right.$ plots): control-the control variant without fertilisers, BW-biochar fertiliser, BWM-biochar fertiliser with mycorrhizal fungi, BWE11 - biochar fertiliser with Bacillus bacteria, BWAbiochar fertiliser with algae, BWAE11 - biochar fertiliser with algae and Bacillus sp. bacteria, BWAM-biochar fertiliser with algae and mycorrhizal fungi.

Lignocellulose pellets with a $10 \%$ porous biochar additive were the substrate on which individual fertiliser variants were based (Table 2).

Table 2. Biochar fertiliser properties at the experimental site.

\begin{tabular}{cc}
\hline Properties & Content \\
\hline Organic C $\left(\mathrm{g} \mathrm{kg}^{-1}\right)$ & 580.11 \\
$\mathrm{~N}\left(\mathrm{~g} \mathrm{~kg}^{-1}\right)$ & 12.35 \\
$\mathrm{P}\left(\mathrm{g} \mathrm{kg}^{-1}\right)$ & 50.8 \\
$\mathrm{~K}\left(\mathrm{~g} \mathrm{~kg}^{-1}\right)$ & 11.85 \\
${\mathrm{Mg}\left(\mathrm{g} \mathrm{kg}^{-1}\right)}_{\mathrm{pH}}^{\mathrm{KCl}}$ & 31.01 \\
\hline
\end{tabular}

Selected microorganisms were applied at a dose of $5 \mathrm{~g}$ or $5 \mathrm{~mL}$ per $300 \mathrm{~g}$ of pellets.

The following commercially available microbiological preparations were used in the experiment: an extract of marine algae of the Ascophyllum nodosum genus, a preparation of mycorrhizal fungi of the Glomus genus (Glomus intraradices, Glomus mosseae, Glomus claroideum, Glomus etunicatum and Gigaspora margarita-round about $5 \cdot 10^{3} \mathrm{CFU}$ per $1 \mathrm{~g}$ of 
preparation), and E11 preparation-a consortium of Bacillus licheniformis, Bacillus azitofixans, Bacillus megaterium and Bacillus subtilis bacteria $\left(10^{8} \mathrm{CFU}\right.$ per $1 \mathrm{~g}$ of preparation).

The dose of E11 preparation and algae extract recommended by the producers is from 15 to $20 \mathrm{~mL}$ per $1000 \mathrm{~g}$ of substrate, hence $5 \mathrm{~g} / 5 \mathrm{~mL}$ of the above-mentioned compositions were added to $300 \mathrm{~g}$ of pellets. The dose of the introduced mycorrhizal fungi preparation was also calculated on the basis of the manufacturer's data, which recommend the introduction of $166 \mathrm{~g}$ of the preparation per $10.000 \mathrm{~g}$ of the medium.

Soil samples for biochemical and microbiological analyses were collected at three terms: I-1st term-one week after fertilisation and sowing, II-2nd term-at the flowering phase, III-3rd term-harvesting phase. The bacterial biodiversity of soil was analysed twice - an aggregate soil sample (control ' 0 ') was collected first at the beginning of the experiment before fertilisation and then at the harvest time.

\subsection{Identification of Soil Microorganisms}

\subsubsection{DNA Extraction}

Total DNA was extracted from $500 \mathrm{mg}$ of each sample with a Genomic Mini AX Soil kit (A\&A Biotechnology, Gdynia, Poland) according to manufacturer's instruction. The extracted DNA was quantified with a Quant-iT HS dsDNA assay kit (Invitrogen, Carlsbad, CA, USA) on a Qubit2 fluorometer (Invitrogen, Carlsbad, CA, USA); $2 \mu \mathrm{L}$ of extracts was examined on $0.8 \%$ agarose gel.

\subsubsection{PCR Amplification}

The metagenomic analysis was based on the hypervariable region V3-V4 of the $16 \mathrm{~S}$ rRNA gene. Specific primers 341F and 785R were used for amplification of this region and to prepare libraries. A PCR was conducted with a Q5 Hot Start High-Fidelity DNA Polymerase kit (NEB Inc., Ipswich, MA, USA). The reaction conditions were maintained according to the manufacturer's specifications. An Illumina MiSeq PE300 sequencer (Genomed S.A., Warsaw, Poland) in $2 \times 250$ bp paired-end (PE) technology with a v2 Illumina chemistry kit was used for sequencing. The reactions were conducted according to the Illumina V3-V4 16S RNA amplification protocol (Illumina, San Diego, CA, USA). The data were analysed automatically with the MiSeq and in the Illumina BaseSpace cloud environment according to the $16 \mathrm{~S}$ Metagenomics protocol (ver. 1.0.1). The libraries were prepared in an analogous way to the attached Illumina protocol.

\subsection{Soil Enzymes Analyses}

Spectrophotometry was used for biochemical analyses. The dehydrogenase activity (DHA) was measured according to the procedure developed by Camiña et al. [33], with some minor modifications. The soil (1 g) with 2, 3, 5-triphenyltetrazolium chloride (TTC) was incubated for $24 \mathrm{~h}$ at $30^{\circ} \mathrm{C}, \mathrm{pH}$ 7.4. Triphenylformazan (TPF) was produced, extracted with $96 \%$ ethanol and measured spectrophotometrically at $485 \mathrm{~nm}$. The dehydrogenase activity was expressed as $\mu$ mol TPF $\mathrm{g}^{-1}$ DM of soil $24 \mathrm{~h}^{-1}$.

The catalyse activity (CAT) in the soil was measured by means of titration [34]. The soil with $0.3 \% \mathrm{H}_{2} \mathrm{O}_{2}$ solution was incubated for $20 \mathrm{~min}$. Next, $1.5 \mathrm{M} \mathrm{H}_{2} \mathrm{SO}_{4}$ was added. The resulting solution was titrated with $0.02 \mathrm{M} \mathrm{KMnO}_{4}$. Catalyse activity was expressed as $\mu \mathrm{mol} \mathrm{H}_{2} \mathrm{O}_{2} \mathrm{~g}^{-1}$ D.M. of soil $\mathrm{min}^{-1}$.

The dehydrogenases and catalyse activity were measured to determine the soil BIF (Biological Index of Fertility) (1) [35]:

$$
\mathrm{BIF}=(1.5 \cdot \mathrm{DHA}+100 \cdot \mathrm{k} \cdot \mathrm{CAT}) / 2
$$

where $\mathrm{k}$-the proportionality coefficient $=0.01$.

\subsection{Plant Analyses}

Before harvesting, all plants from the two middle rows were counted to determine the plant density. The share of plants with stem fusariosis and Fusarium cob wilt was 
determined in the same rows. Maize cobs from the two middle rows were harvested manually. On harvesting, the percentage of cobs with lesions caused by infection with Fusarium sp. was determined [36]. Seeds from three hand-threshed cobs were assessed for their moisture content with the gravimetric method. The other cobs were dried in a room and threshed with a dedicated cob peeler. A moisture content of $15 \%$ was assumed to calculate the yield. A thousand kernel weight was determined by weighing 500 seeds twice. The starch content was measured with the polarimetric method, as specified in the European Commission Regulation (EC) No. 152/2009 of 27 January 2009 [37]. The method consisted of two measurements. First, the samples were treated with dilute hydrochloric acid in a boiling water bath. After clarification with Carrez solutions I and II (Chempur) and filtration, the optical rotation of the solutions was measured in a 200-mm polarimetric tube (Polarimeter Insmark IP-digi1). In the second measurement, the samples were extracted with $40 \%$ ethanol. The filtrate was acidified with hydrochloric acid, clarified with Carrez solutions I and II, and filtered to measure the optical rotation as in the first measurement. The result of the difference between the two measurements multiplied by the known factor was the starch content in the samples. The ash content was measured with the combustion method. The crude protein content was calculated on the basis of the nitrogen content determined with the Kiejdahl method. One-gram samples were mineralised in concentrated sulphuric acid $\left(\rho 20=1.84 \mathrm{~g} \mathrm{~mL}^{-1}\right)$ with the Cu-Se catalyst (Sharlab CA03931000) in a digestion oven (Hanon Instruments SH420F). Ammonia was distilled and titrated in an automatic distiller with a titrator (Hanon Instruments K110F).

\subsection{Statistical and Bioinformatics Analyses}

The data were subjected to a conventional analysis of variance with STATISTICA ${ }^{\circledR}$ 10 software (StatSoft, Krakow, Poland). The differences between the treatments were analysed with Tukey's test $(p \leq 0.05)$. The Pearson correlation coefficient was used to quantify the strength of the relationship between the dehydrogenase activity and the $\mathrm{pH}$ value.

Demultiplexed fastq files were processed with the DADA2 (1.14) package [38] in $R$ software (3.6.0) [39]. On the basis of the quality plots the last 20 and 70 bases were trimmed off forward and reverse reads accordingly. Primer sequences were removed from all the reads. The filter parameters were as follows: $\max N=0, \max E E$ for both reads $=2$, truncQ $=2$. The error rates were estimated by learnErrors with one million reads. Exact sequence variants were resolved with dada. Next, removeBimeraDenovo was used to remove chimeric sequences. After the filtration steps 111.413-142.459 (mean =131,475) of the reads were left for further analysis. Taxonomy was assigned against the latest version of the modified RDP v18 database (link) using the IDTAXA algorithm [40] and the table of sequences resulting from the DADA2 workflow described above. The results were converted and imported into the phyloseq (1.22.3) package [41]. Sequences belonging to the chloroplast or mitochondrial DNA were removed. Subsequently, for further analysis, the total number of reads for the individual taxa was converted into a percentage, assuming the sum of all taxa in the individual samples was $100 \%$. On average, $55 \%$ of all reads which were correctly classified to the genus level were aggregated and their abundances were summed up. Unclassified reads were clustered with vsearch [42] implemented in seed software, version 2.1 [43] at a 99\% similarity level.

Venn diagrams were used to show the similarities and differences in the species composition of experimental variants representing the reactions of maize and soil enzymes to the type of biofertiliser applied. The datasets were also analysed with canonical variate analysis (CVA), a form of multivariate analysis, which enables visualisation of the relationships between experimental variants and the variables that describe them [44-46]. This method, similar to principal component analysis, was chosen because it considers differences between groups [47]. The relations between selected experimental variants described by the reactions of maize and soil enzymes to the type of biofertiliser applied were analysed with canonical variate analysis based on transformation by linear combi- 
nation [47] and singular value decomposition [48,49]. The CVA also showed relations between the variables (BIF, soil $\mathrm{pH}$, chemical parameters, and yield) by determining the components being a linear combination of these variables.

\section{Results and Discussion}

\subsection{Abundance and Composition of Bacterial Community in Soil}

In order to determine the metapopulation changes in soil bacteria under the maize plantation, the 16S rRNA gene was analysed. Each of the soil samples contained more than $99 \%$ of bacteria, $0.01-0.02 \%$ of Archaea, and $0.02-0.03 \%$ of unclassified microorganisms.

The metataxonomic analysis of the $16 \mathrm{~S}$ soil metabiome showed that the soil samples were biodiversified, as they contained 30 bacterial phylum and 798 genera. Due to such a large number of operational taxonomic units (OTUs) only the most common ones were represented graphically.

Only nine of all the bacterial phylum found in all experimental variants had a greater share than $0.6 \%$ (Actinobacteria, Proteobacteria, Firmicutes, Planctomycetes, Acidobacteria, Verrucomicrobia, Bacteroidetes, Chloroflexi, and Gemmatimonadetes) (Figure 1).

There were three dominant bacterial phylum at the study site: Actinobacteria $(29.69-62.23 \%$ of all phylum isolated, depending on the experimental variant), Proteobacteria (19.04-35.79\%) and Firmicutes (8.53-13.78\%). Apart from that, the share of unclassified sequences of microorganisms in the soil samples under analysis ranged from $4.16 \%$ to $7.32 \%$. According to Furtak et al. [50], data analysis should take all sequences of microorganisms into account, including the unclassified ones. They cannot be ignored or averaged and treated collectively as unclassified taxa, because the contribution of individual unclassified taxa to the structure of the soil bacterial community is very high (from 3.5\% to as much as $99 \%$ ). Moreover, they are characterised by high sensitivity to changes in the environment and have the highest share in changes occurring in soil [51,52].

The research results show that both the cultivation of maize and the additive of biofertilisers based on biochar and selected microorganisms had an influence on the percentage of individual bacterial phylum in the soil. The cultivation of maize limited the proliferation of Actinobacteria and Gemmatimonadetes but increased the content of sequences of unclassified bacteria as well as Proteobacteria, Firmicutes, and Planctomycetes.

According to Breidenbach et al. [53], plants modify the condition of the soil microbiome with root exudates. These authors observed that Firmicutes were abundant in the maize rhizosphere, but they were the dominant bacterial phylum in a rice plantation.

The results of our study also show that the control soil (the control variant) and the soil treated with innovative biofertilisers differed in the structure and percentage share of individual bacterial phylum in microbial communities. All variants treated with fertilisers had a lower content of Proteobacteria, Firmicutes, Acidobacteria and sequences of unclassified bacteria. By contrast, the fertilisers increased the content of Actinobacteria, which was on average 17.58-98.45\% higher than in the unfertilised soil (the control variant). The highest content of Actinobacteria was found in the variant with mycorrhizal fungi (BWM).

Francioli et al. [54] also observed that organic fertilisation had a significant influence on the community of soil bacteria. However, the results of their research showed that manure fertilisation increased the diversity of the Firmicutes and Proteobacteria bacterial phylum, which are known to prefer nutrient-rich environments and to participate in the degradation of complex organic compounds. By contrast, in the soil where no manure was applied there were different communities of oligotrophic microorganisms adapted to nutrient-restricted environments such as Acidobacteria.

As results from the studies cited above and the observations made in our research show, the type of organic fertilisation and its chemical composition significantly affect the succession of soil microorganisms. A narrower $\mathrm{C}: \mathrm{N}$ ratio in manure will certainly result in faster nitrogen mineralisation in the soil than the applied crop residues with the biochar additive, where the $\mathrm{C}: \mathrm{N}$ ratio is wider. 


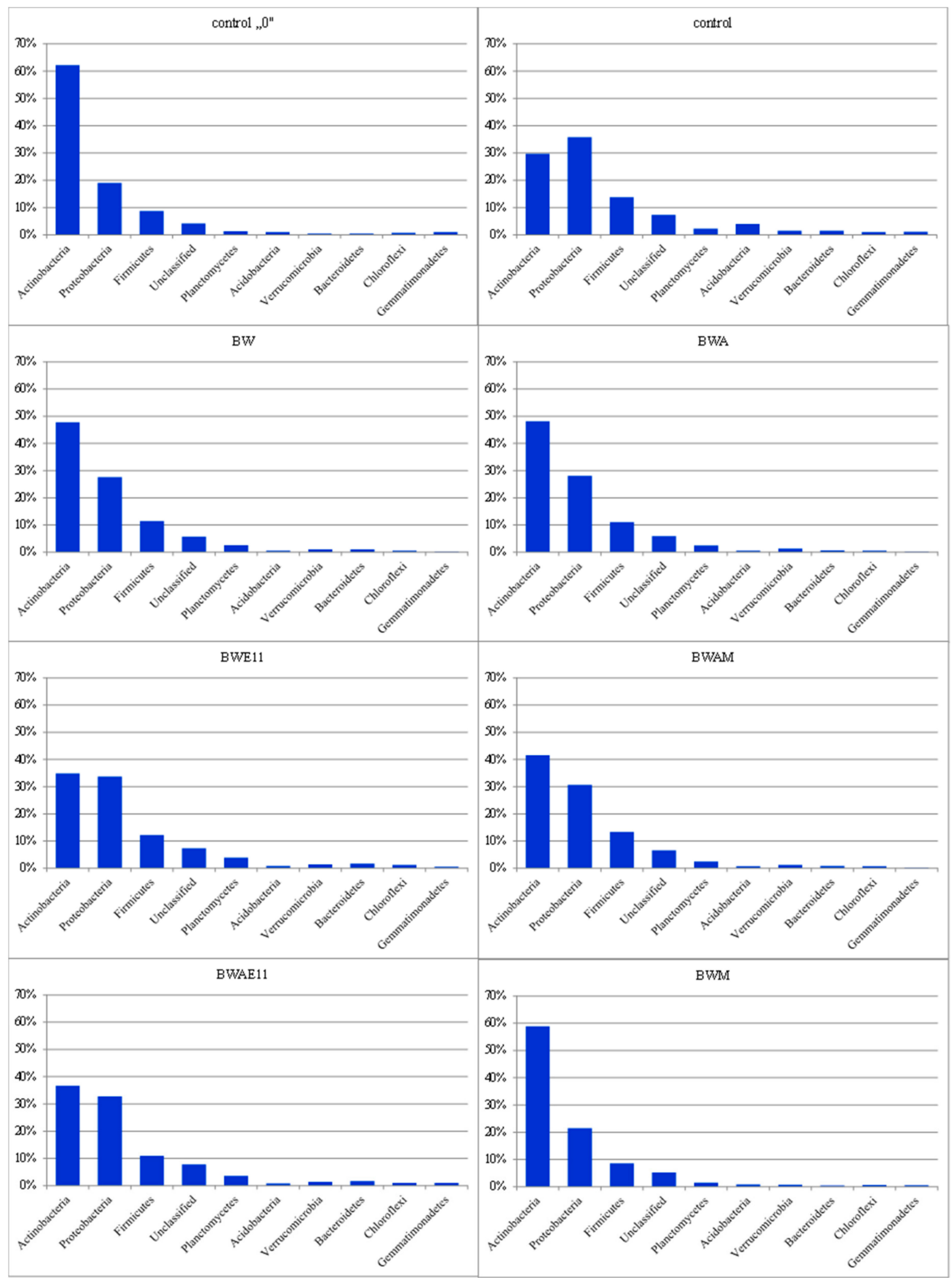

Figure 1. The percentage content of selected bacterial phylum in the experimental variants. Explanation: control ' 0 ' - without fertilisers and plant cultivation, control - the control variant without fertilisers, with plant cultivation, BWbiochar fertiliser, BWM-biochar fertiliser with mycorrhizal fungi, BWE11—biochar fertiliser with Bacillus bacteria, BWAbiochar fertiliser with algae, BWAE11—biochar fertiliser with algae and Bacillus sp. bacteria, BWAM-biochar fertiliser with algae and mycorrhizal fungi. 
The metataxonomic analysis of the soil metabiome based on $16 \mathrm{~S}$ sequencing showed that the type of the tested variant also influenced the structure of the bacterial microbiome (Figure 2).

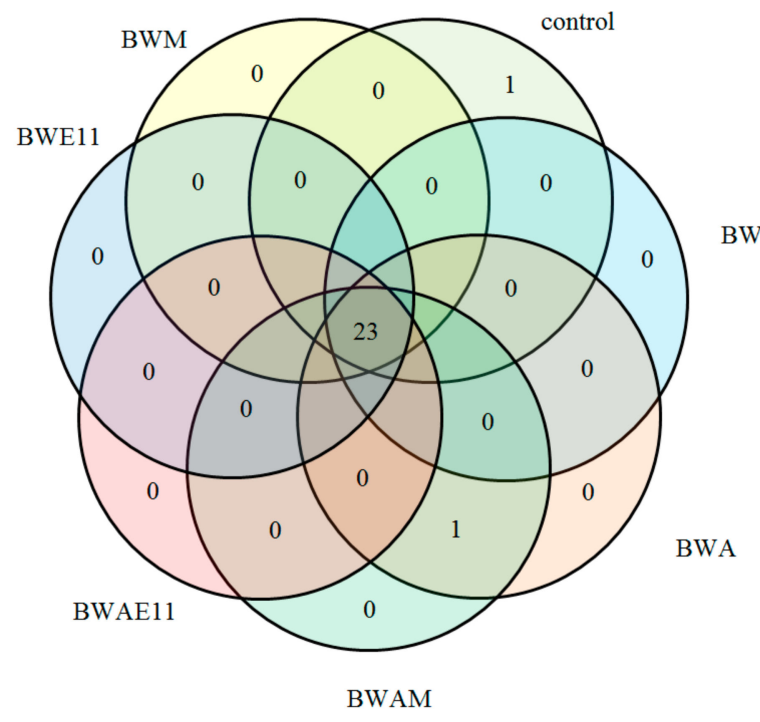

(A)

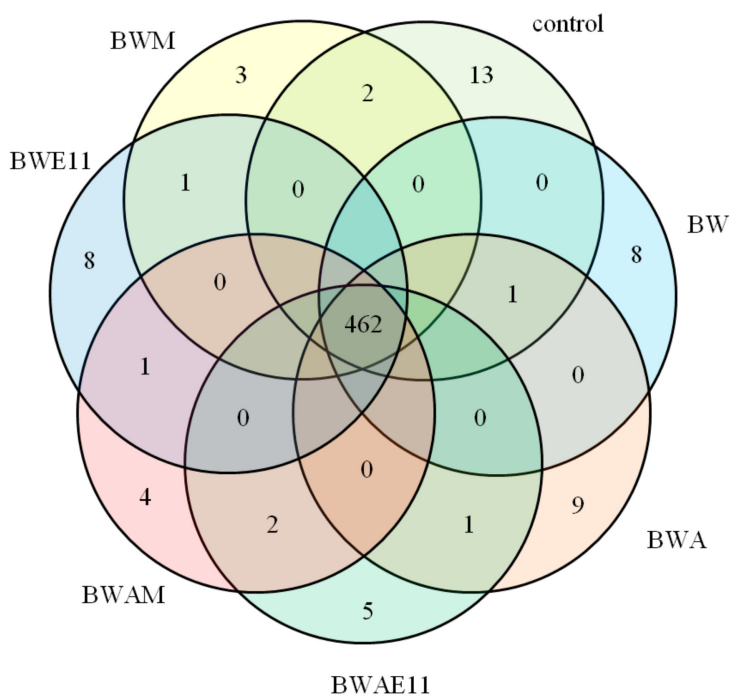

(B)

Figure 2. A Venn diagram of overlapping bacterial communities from the variants ((A)—phylum, (B)—genus) Explanation: control ' 0 ' - without fertilisers and plant cultivation, control-the control variant without fertilisers, with plant cultivation, BW-biochar fertiliser, BWM-biochar fertiliser with mycorrhizal fungi, BWE11—biochar fertiliser with Bacillus bacteria, BWA-biochar fertiliser with algae, BWAE11—biochar fertiliser with algae and Bacillus sp. bacteria, BWAM-biochar fertiliser with algae and mycorrhizal fungi.

Of all taxa found within a given category, 23 bacterial phylum and 462 genera that were common to all variants were selected. There were unique bacterial sequences found in the BWA and BWAM variants-they belonged to the anaerobic, chemoorganotrophic phylum Caldiserica [55]. The presence of the Chrysiogenets phylum, which includes anaerobic strains exhibiting bioremediation abilities, was noted only in the BWAE11 and BWM variants, as well as in the control variant. The control variant was the only one which contained Fibrobacteres — the phylum of cellulolytic aerobic bacteria, commonly found in soil $[56,57]$. The control variant had the most unique taxa at the genus level (Table 3).

Table 3. Unique bacterial taxa in individual experimental variants.

\begin{tabular}{|c|c|c|c|c|c|c|c|}
\hline \multicolumn{8}{|c|}{ Variant } \\
\hline Control ‘ 0 ’ & Control & BW & BWM & BWE11 & BWA & BWAE11 & BWAM \\
\hline \multicolumn{8}{|c|}{ Number of Unique Taxa } \\
\hline 8 & 13 & 8 & 3 & 8 & 9 & 5 & 4 \\
\hline $\begin{array}{c}\text { Dethiobacter } \\
\text { Alloscardovia } \\
\text { Desulfosporomusa } \\
\text { Desulfurococcus } \\
\text { Providencia } \\
\text { Salisaeta } \\
\text { Trabulsiella } \\
\text { Vagococcus }\end{array}$ & $\begin{array}{c}\text { Bizionia } \\
\text { Butyrivibrio } \\
\text { Fibrobacter } \\
\text { Fusobacterium } \\
\text { Melissococcus } \\
\text { Nevskia } \\
\text { Nitrincola } \\
\text { Rapidithrix } \\
\text { Sporanaerobacte } \\
\text { Thiovirga } \\
\text { Alkanindiges } \\
\text { Citrobacter } \\
\text { Tepidimicrbium }\end{array}$ & $\begin{array}{c}\text { Candidatus Az. } \\
\text { Ignatzschineria } \\
\text { Arsenicicoccus } \\
\text { Azorhizophilus } \\
\text { Candidatus Ph. } \\
\text { Kurthia } \\
\text { Porphyromonas } \\
\text { Stenoxybacter }\end{array}$ & $\begin{array}{c}\text { Phormidium } \\
\text { Anaerostipes } \\
\text { Geovibrio }\end{array}$ & $\begin{array}{c}\text { Erwinia } \\
\text { Anaerotruncus } \\
\text { Mogibacterium } \\
\text { Planktothrix } \\
\text { Dickeya } \\
\text { Pseudanabaena } \\
\text { Reinekea } \\
\text { Verrucomicrobium }\end{array}$ & $\begin{array}{c}\text { Muricauda } \\
\text { Acidianus } \\
\text { Anaeromusa } \\
\text { Anaeroplasma } \\
\text { Martelella } \\
\text { Natranaerobius } \\
\text { Rothia } \\
\text { Succinivibrio } \\
\text { Trichococcus }\end{array}$ & $\begin{array}{c}\text { Cellvibrio } \\
\text { Desulfobacterium } \\
\text { Nitrospina } \\
\text { Ruminococcus } \\
\text { Sediminibacterium }\end{array}$ & $\begin{array}{c}\text { Pseudochrobactrum } \\
\text { Elizabethkingia } \\
\text { Halanaerobacter } \\
\text { Herpetosiphon }\end{array}$ \\
\hline
\end{tabular}

Explanation: control ' 0 ' —-without fertilisers and plant cultivation, control一the control variant without fertilisers, with plant cultivation, BW—biochar fertiliser, BWM-biochar fertiliser with mycorrhizal fungi, BWE11—biochar fertiliser with Bacillus bacteria, BWA—biochar fertiliser with algae, BWAE11—biochar fertiliser with algae and Bacillus sp. bacteria, BWAM—biochar fertiliser with algae and mycorrhizal fungi. 
One of them was the Fibrobacter genus, which included strains promoting plant growth and development such as Fibrobacter succinogenes. These Gram-negative, anaerobic or facultative anaerobic bacteria can be found in the rumen. As they produce numerous enzymes responsible for the carbon cycle, they significantly affect the mineralisation of organic matter in soil and thus provide nutrients to plants [58].

The metataxonomic analysis of the maize rhizosphere also showed that the autochthonous saprophytic bacterial genera Arthrobacter and Saccharopolyspora had the highest percentage of sequences. These taxonomic units include species which can degrade various simple and complex organic compounds in soil, exhibit phytosanitary capacity against plant pathogens and can fix atmospheric nitrogen $[59,60]$ (Figure 3).

The comparison of the percentage of bacteria in the control variant ' 0 ' with the other experimental variants showed that the cultivation of maize reduced the number of operational taxonomic units of the Nocardioides, Aeromicrobium, Phycicoocus, and Streptomyces genera but increased the content of sequences belonging to the Kaistobacter, Colnella, Iamia, and Candidatus Scalindua genera. It is most likely that this reaction of microorganisms was caused by the chemical profile of maize root exudates, which contain glucose, fructose, sucrose, lactic acid, citric acid, succinic acid, serine, alanine, and glutamic acid. According to Baudoin et al. [61] and Wolna-Maruwka et al. [62], they can stimulate or inhibit the soil microbiome.

The metataxonomic analysis showed that the application of fertilisers based on biochar and selected microorganisms caused both quantitative and structural changes in the soil bacterial community (Figure 2).

The use of the biofertiliser without microorganisms (the BW variant) and the biofertiliser inoculated with mycorrhizal fungi (the BWM variant) increased the proliferation of bacteria of the Arthrobacter genus. Moreover, in comparison with the control variant, all fertiliser variants increased the percentage of sequences belonging to the following genera: Clostridium, Iamia, Streptomyces, Phycicoccus, Conexibacter, Nocardioides, Aeromicrobium, and Saccharopolyspora.

Eight new bacterial genera were found in the soil after the treatment with the biofertiliser without microorganisms (the BW variant). The application of the biofertiliser with algae (BWA) revealed nine new bacterial genera, the E11 additive revealed eight (BWE11), whereas the biofertiliser with mycorrhizal fungi revealed only three new genera. The study by Tian et al. [63] showed that the biochar treatment of a rice plantation caused changes in both the biomass and the soil microbial community. Nevertheless, this was not a long-term effect because the content of nitrogen in soil was limited by its immobilisation in the microbial biomass after the treatment with biochar only, without an additional source of nitrogen, for example in the form of NPK.

On the other hand, according to Elzobair et al. [64], the application of biochar to soil had only a minimal influence on the structure of microbial communities, the microbial biomass, and the colonisation of roots by mycorrhizal fungi. The authors suggested that the influence of biochar on microbial communities largely depends on its dose and type, as well as the chemical composition of the soil. According to Chen et al. [65], the structure of a microbial community changes when a dose of biochar is high enough to significantly alter the water-holding capacity of soil, its $\mathrm{pH}$ and concentration of nutrients, which are the most critical factors affecting soil microbial diversity.

Our study showed that the structure of the bacterial microbiome value may have been influenced by the $\mathrm{pH}$ value. The decrease in the $\mathrm{pH}$ value in all biochar fertiliser variants was smaller than in the control variant (Figure 4). The microorganisms applied with the fertiliser into the soil may also have affected its bacterial biodiversity. There are various, both symbiotic and antagonistic, interactions between soil microorganisms, especially in the rhizosphere [66,67]. 


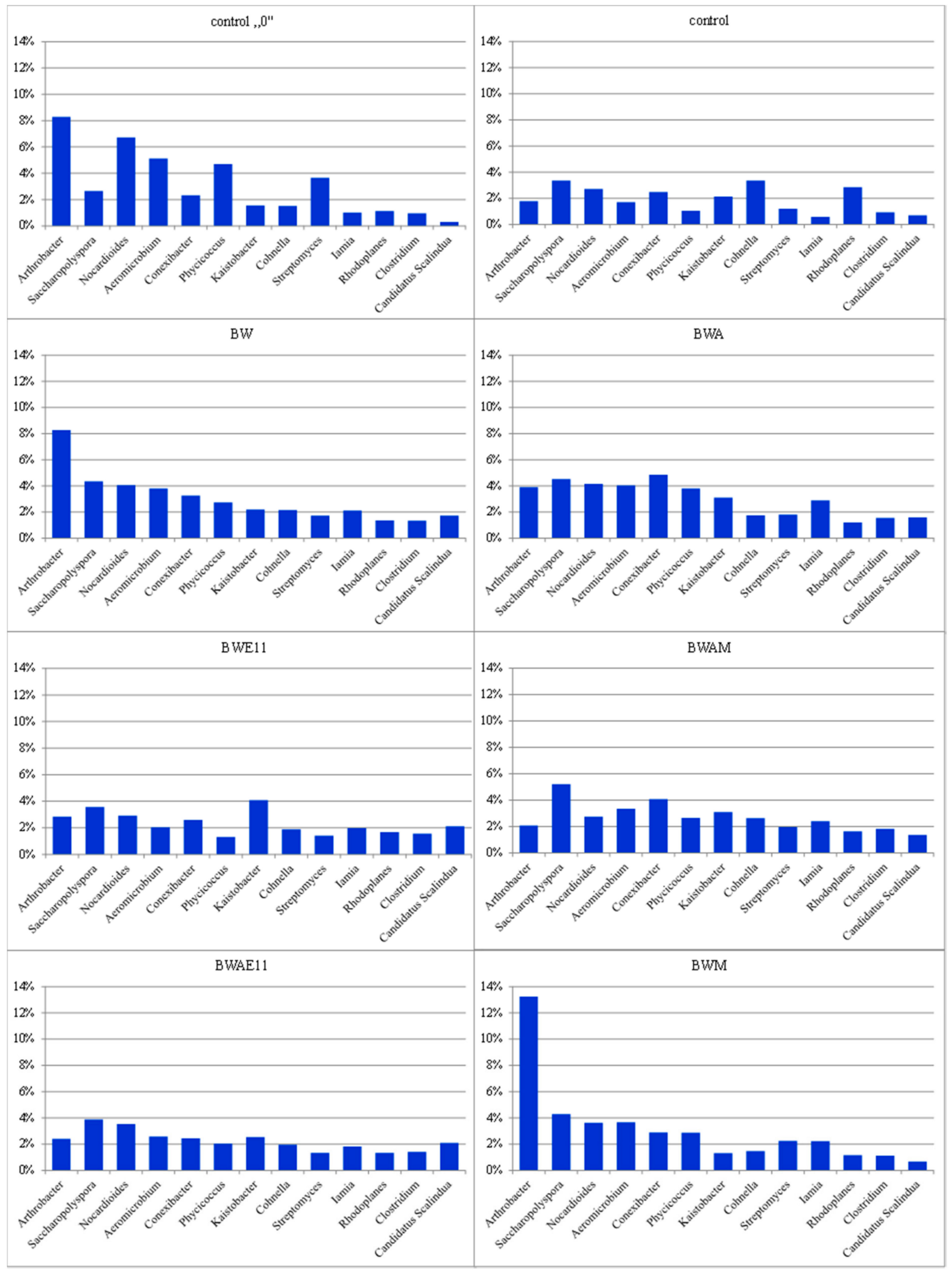

Figure 3. The percentage content of selected bacterial genus in the experimental variants. Explanation: control ' 0 '—without fertilisers and plant cultivation, control—the control variant without fertilisers, with plant cultivation, BW-biochar fertiliser, BWM-biochar fertiliser with mycorrhizal fungi, BWE11—biochar fertiliser with Bacillus bacteria, BWA-biochar fertiliser with algae, BWAE11—biochar fertiliser with algae and Bacillus sp. bacteria, BWAM-biochar fertiliser with algae and mycorrhizal fungi. 


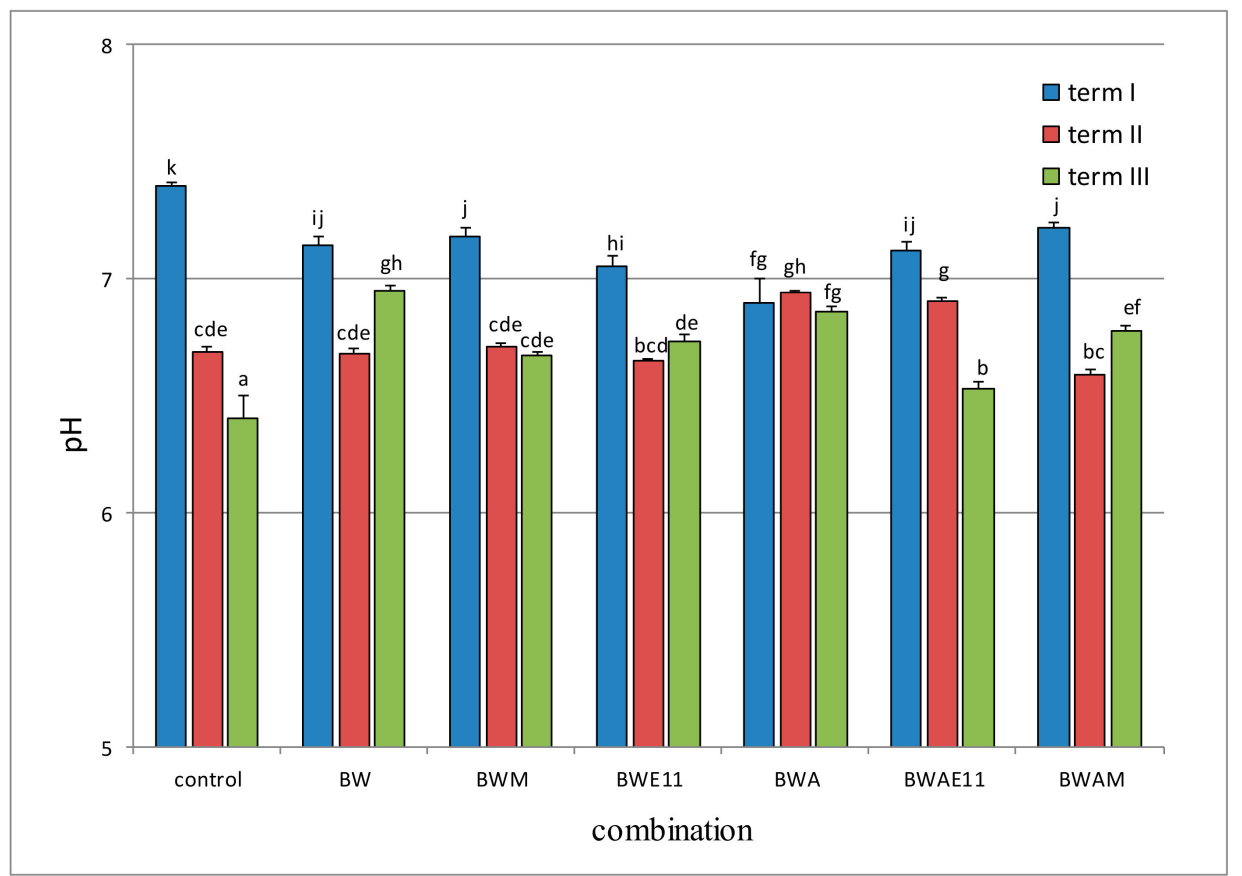

Figure 4. The changes of the $\mathrm{pH}$ value of soil. Explanation: Means followed by the same letters do not differ significantly at $p \leq 0.05$; control-the control variant without fertilisers, BW-biochar fertiliser, BWM-biochar fertiliser with mycorrhizal fungi, BWE11-biochar fertiliser with Bacillus bacteria, BWA-biochar fertiliser with algae, BWAE11—biochar fertiliser with algae and Bacillus sp. bacteria, BWAM — biochar fertiliser with algae and mycorrhizal fungi; I-1st term—one week after fertilisation and sowing, II—2nd term—at the flowering phase, III—3rd term—harvesting phase.

The research by Rangel-Castro et al. [68] and Landeweert et al. [69] showed that soluble storage sugars (usually trehalose), polyols (e.g., mannitol), and organic acids, especially oxalic acid produced by mycorrhizal fungi (AM), were the main factors affecting the selection of bacteria in the rhizosphere. Fungus-specific antibiotics also influence the formation of the microbiome of soil bacteria [70]. Rillig [71] also observed the indirect effect of mycorrhizal fungi on bacteria, which stimulated the growth of roots. They also changed the qualitative and quantitative composition of root exudates modifying the physicochemical properties of soil, which translated into the succession of soil bacteria. These observations clearly explain why in our study the lowest number of unique bacterial genera was found in the variants with mycorrhizal fungi (variants BWM and BWAM) (Table 3).

\subsection{Changes in Soil $p H$ and Dehydrogenase Activity}

Due to the properties and chemical composition of biochar, its influence on the soil $\mathrm{pH}$ (Figure 4) and the biochemical index of fertility (BIF) was assessed on the basis of the activity of dehydrogenases and catalase (Figure 5). These enzymes occur in soil as an integral part of intact microbial cells. Their activity is treated as an index of the intensity of the respiratory metabolism of soil microorganisms [72,73].

The analysis of the research results shown in Figure no. 5 reveal that the biofertilisers applied to the soil during the experiment did not significantly affect the BIF level, apart from the BWM and BW variants. The highest BIF value was noted at the second and third terms of the study in the soil treated with the biofertiliser and mycorrhizal fungi (the BWM variant).

Results from the study by Vázquez et al. [74] show that plants with a low degree of dependence on mycorrhizal associations, such as maize, are a suitable object to evaluate the type of biochemical processes occurring in the rhizosphere. The use of maize as a model plant producing large amounts of root exudates enables the assessment of how the colonisation of roots with mycorrhizal fungi influences the size of the microbial population 
in the rhizosphere and soil enzymology. The authors observed that the inoculation of maize with fungi of the Glomus genus stimulated soil enzymatic activity. This effect was also observed in our study (Figure 5).

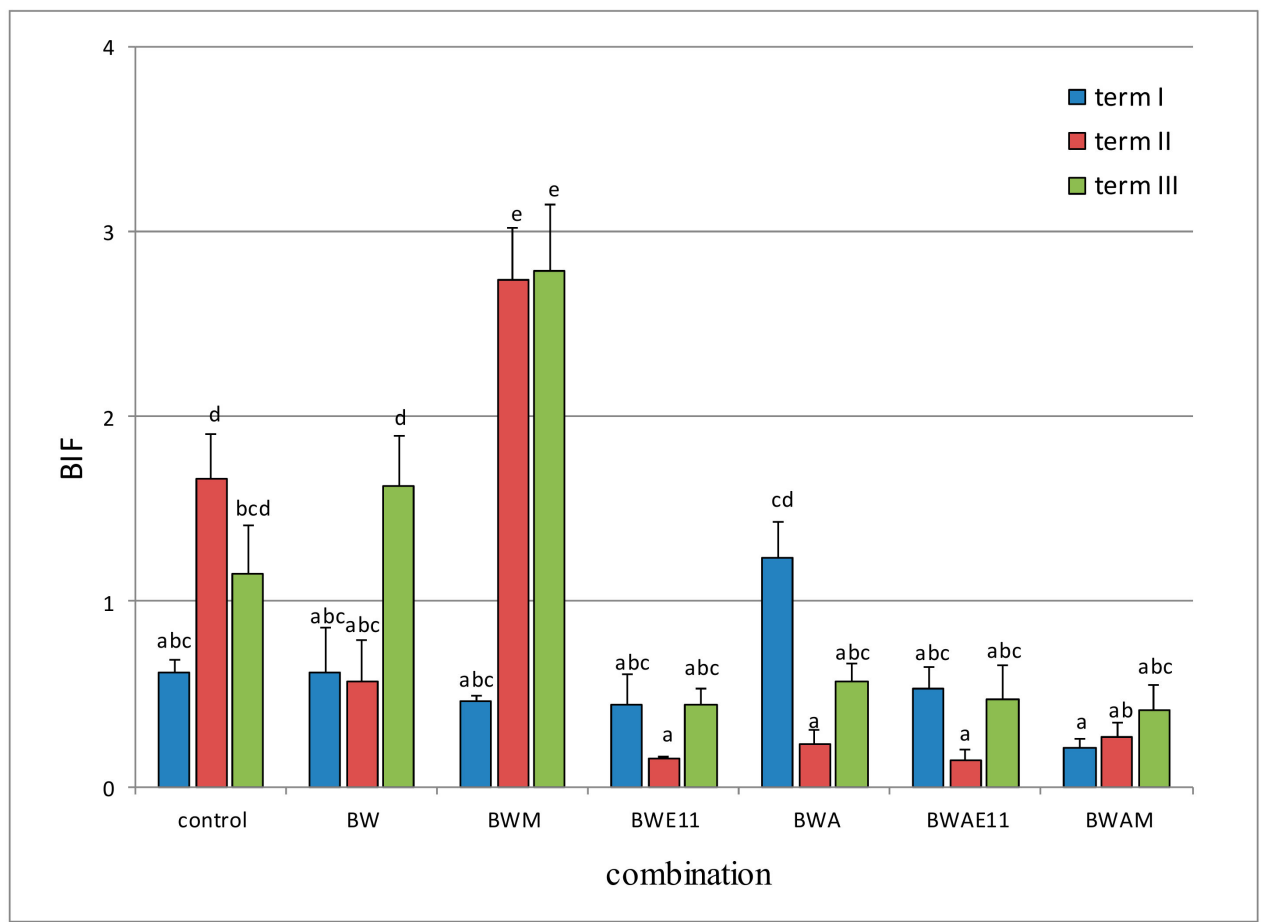

Figure 5. The changes of Biological Index of Fertility (BIF) in a soil. Explanation: Means followed by the same letters do not differ significantly at $p \leq 0.05$; control-the control variant without fertilisers, BW—biochar fertiliser, BWM-biochar fertiliser with mycorrhizal fungi, BWE11—biochar fertiliser with Bacillus bacteria, BWA-biochar fertiliser with algae, BWAE11-biochar fertiliser with algae and Bacillus sp. bacteria, BWAM-biochar fertiliser with algae and mycorrhizal fungi; I-1st term—one week after fertilisation and sowing, II—2nd term—at the flowering phase, III—3rd term-harvesting phase.

The strongest negative correlation between the level of enzymatic activity and the soil $\mathrm{pH}$ was noted in the BWM variant (2). The lowering of the $\mathrm{pH}$ value during the experiment (Figure 4) favoured the development of mycorrhizal fungi, and in consequence, increased the activity of the soil enzymes under analysis.

$$
\mathrm{pH}=-0.2492 \mathrm{BIF}+7.3772 \text { for } \mathrm{R}^{2}=0.9982, p \leq 0.01
$$

According to Wolna-Maruwka et al. [75], the soil $\mathrm{pH}$ is a major factor affecting the activity of soil enzymes. During our experiment the $\mathrm{pH}$ value was gradually decreasing in all variants. The lowest value of this parameter $(\mathrm{pH}=6.2)$ was noted in the control variant at the third term, which can be explained by the cultivation of maize [76].

The comparison of the dynamics of changes in the soil enzymatic activity in the experimental variants at subsequent terms showed that the cultivation of maize significantly influenced the BIF value. Hupe et al. [77] also observed that the phase of plant development significantly influenced the dynamics of nutrients in the rhizosphere, and thus the soil enzymatic activity. The researchers observed intensive deposition of carbon and nitrogen in the rhizosphere in the period extending from the emergence of plants to their flowering. They stressed the fact that after flowering, the amount of nitrogen deposited in the rhizosphere was significantly inhibited and explained this effect by the displacement of nitrogen in the plants to produce the yield. According to these authors, after the flowering 
period the amount of organic nitrogen substances in relation to carbon was reduced in the rhizosphere due to the lower metabolic activity of soil enzymes.

\subsection{Plant Parameters}

The weather conditions during the study had a strong, negative influence on the maize yield. Both growing seasons were dry and extremely hot $[78,79]$. The average maize yield in the control variant was $6.94 \mathrm{t} \mathrm{ha}^{-1}$ (Table 4). The application of biochar without additives had no effect on the yield of maize seeds $\left(6.98 \mathrm{tha}^{-1}\right)$. Biochar often has a positive effect on the yield $[80,81]$ but it must be applied into soil at very high doses, i.e., $20-100 \mathrm{t} \mathrm{ha}^{-1}$.

Table 4. The influence of the applied preparations on the yield of maize seeds and other yield components.

\begin{tabular}{|c|c|c|c|c|c|c|c|}
\hline Variants & $\begin{array}{l}\text { Yield of } \\
\text { Seeds } \\
\left(\mathrm{t} \mathrm{ha}^{-1}\right)\end{array}$ & $\begin{array}{c}\text { Plant } \\
\text { Density } \\
\left(\text { No. } \mathrm{m}^{-2}\right)\end{array}$ & $\begin{array}{c}\text { Number of } \\
\text { Cobs per } \\
\text { Plant }\end{array}$ & $\begin{array}{c}\text { Number Of } \\
\text { Seeds per } \\
\text { Cob }\end{array}$ & $\begin{array}{c}\text { Thousand } \\
\text { Kernel } \\
\text { Weight (g) }\end{array}$ & $\begin{array}{c}\text { Moisture } \\
\text { Content at } \\
\text { Harvest (\%) }\end{array}$ & $\begin{array}{l}\text { Number of } \\
\text { Cobs per } \mathrm{m}^{2}\end{array}$ \\
\hline control & $\begin{array}{c}6.94 \mathrm{~b} \\
( \pm 1.36)\end{array}$ & $\begin{array}{c}6.65 \mathrm{a} \\
( \pm 0.26)\end{array}$ & $\begin{array}{c}0.87 \mathrm{a} \\
( \pm 0.02)\end{array}$ & $\begin{array}{l}360 \mathrm{a} \\
( \pm 60)\end{array}$ & $\begin{array}{l}281 \mathrm{a} \\
( \pm 8)\end{array}$ & $\begin{array}{l}22.8 \mathrm{a} \\
( \pm 1.6)\end{array}$ & $\begin{array}{c}5.8 \mathrm{a} \\
( \pm 0.13)\end{array}$ \\
\hline BW & $\begin{array}{l}6.98 \mathrm{ab} \\
( \pm 1.09)\end{array}$ & $\begin{array}{c}7.20 \mathrm{a} \\
( \pm 0.17)\end{array}$ & $\begin{array}{c}0.81 \mathrm{a} \\
( \pm 0.04)\end{array}$ & $\begin{array}{l}352 \mathrm{a} \\
( \pm 58)\end{array}$ & $\begin{array}{l}279 \mathrm{a} \\
( \pm 4)\end{array}$ & $\begin{array}{l}19.3 \mathrm{ab} \\
( \pm 0.5)\end{array}$ & $\begin{array}{c}5.8 \mathrm{a} \\
( \pm 0.19)\end{array}$ \\
\hline BWM & $\begin{array}{c}8.83 \mathrm{a} \\
( \pm 1.39)\end{array}$ & $\begin{array}{c}7.10 \mathrm{a} \\
( \pm 0.17)\end{array}$ & $\begin{array}{c}0.89 \mathrm{a} \\
( \pm 0.01)\end{array}$ & $\begin{array}{l}437 \mathrm{a} \\
( \pm 67)\end{array}$ & $\begin{array}{l}289 \mathrm{a} \\
( \pm 9)\end{array}$ & $\begin{array}{l}18.0 \mathrm{~b} \\
( \pm 2.7)\end{array}$ & $\begin{array}{c}5.9 \mathrm{a} \\
( \pm 0.12)\end{array}$ \\
\hline BWE11 & $\begin{array}{l}7.40 \mathrm{ab} \\
( \pm 1.42)\end{array}$ & $\begin{array}{c}6.73 \mathrm{a} \\
( \pm 0.16)\end{array}$ & $\begin{array}{c}0.87 \mathrm{a} \\
( \pm 0.02)\end{array}$ & $\begin{array}{l}385 \mathrm{a} \\
( \pm 80)\end{array}$ & $\begin{array}{l}280 \mathrm{a} \\
( \pm 5)\end{array}$ & $\begin{array}{l}22.4 \mathrm{a} \\
( \pm 0.9)\end{array}$ & $\begin{array}{c}5.9 \mathrm{a} \\
( \pm 0.13)\end{array}$ \\
\hline BWA & $\begin{array}{l}7.89 \mathrm{ab} \\
( \pm 1.32)\end{array}$ & $\begin{array}{c}6.42 \mathrm{a} \\
( \pm 0.10)\end{array}$ & $\begin{array}{c}0.91 \mathrm{a} \\
( \pm 0.02)\end{array}$ & $\begin{array}{l}429 \mathrm{a} \\
( \pm 53)\end{array}$ & $\begin{array}{l}279 \mathrm{a} \\
( \pm 16)\end{array}$ & $\begin{array}{l}21.5 \mathrm{ab} \\
( \pm 1.2)\end{array}$ & $\begin{array}{c}5.8 \mathrm{a} \\
( \pm 0.14)\end{array}$ \\
\hline BWAE11 & $\begin{array}{l}7.46 \mathrm{ab} \\
( \pm 1.32)\end{array}$ & $\begin{array}{c}7.15 \mathrm{a} \\
( \pm 0.24)\end{array}$ & $\begin{array}{c}0.82 \mathrm{a} \\
( \pm 0.02)\end{array}$ & $\begin{array}{l}386 \mathrm{a} \\
( \pm 58)\end{array}$ & $\begin{array}{l}277 \mathrm{a} \\
( \pm 12)\end{array}$ & $\begin{array}{l}20.0 \mathrm{ab} \\
( \pm 1.1)\end{array}$ & $\begin{array}{c}5.8 \mathrm{a} \\
( \pm 0.17)\end{array}$ \\
\hline BWAM & $\begin{array}{l}8.02 \mathrm{ab} \\
( \pm 1.25)\end{array}$ & $\begin{array}{c}6.85 \mathrm{a} \\
( \pm 0.21)\end{array}$ & $\begin{array}{c}0.88 \mathrm{a} \\
( \pm 0.03)\end{array}$ & $\begin{array}{l}407 a \\
( \pm 48)\end{array}$ & $\begin{array}{l}283 \mathrm{a} \\
( \pm 14)\end{array}$ & $\begin{array}{l}21.3 \mathrm{ab} \\
( \pm 0.7)\end{array}$ & $\begin{array}{c}6.0 \mathrm{a} \\
( \pm 0.10)\end{array}$ \\
\hline $\operatorname{LSD}_{(0.05)}$ & 1.88 & ns & $\mathrm{ns}$ & ns & $\mathrm{Ns}$ & 4.3 & ns \\
\hline
\end{tabular}

Explanation: Means followed by the same letters do not differ significantly at $p \leq 0.05$; ns-insignificant; control—the control variant without fertilisers, BW-biochar fertiliser, BWM-biochar fertiliser with mycorrhizal fungi, BWE11—biochar fertiliser with Bacillus bacteria, BWA — biochar fertiliser with algae, BWAE11—biochar fertiliser with algae and Bacillus sp. bacteria, BWAM—biochar fertiliser with algae and mycorrhizal fungi.

Although in our experiment biochar was applied in a localised manner, near the row of plants, its dose was too small to affect the yield of maize seeds. However, the maize yield tended to increase in all the combinations where the soil was fertilised with biochar enriched with additional components, especially mycorrhizal fungi in the BWAM and BWM variants. The yield of maize seeds in the BWM variant was $1.89 \mathrm{t} \mathrm{ha}^{-1}$ higher than in the control variant. Mycorrhiza is even more important for maize cultivation when plants grow under difficult conditions, usually with low availability of phosphorus, exposed to drought stress and other adverse factors [82]. Climate change increases the frequency of occurrence of extreme weather phenomena. Additionally, the natural colonisation of roots by mycorrhizal fungi is limited by the common practice of intensive tillage [83].

On harvesting, the maize grown in the soil fertilised with BWM was characterised by lower moisture and ash content but higher starch content (Table 5). Post-harvest drying of maize seeds is one of the most important costs of growing this crop [84].

In Poland, maize is harvested by combine harvesters as soon as it is possible, i.e., when humidity is about $30 \%$. The extremely low moisture content in the harvested maize seeds was mainly caused by the extremely hot and dry weather during the research years. The BWM fertiliser additionally reduced the water content in the seeds by almost five percentage points, which significantly facilitated harvesting and reduced the cost of drying.

The faster drying of maize cobs also reduces the risk of fusariosis in caryopses. During our study the occurrence of Fusarium sp. on the maize stems and cobs was very low. There were few infested plants regardless of the experimental combination. Dry and hot weather is one of the most important factors limiting the occurrence of Fusarium sp. in maize 
plants [85]. Due to such low pressure of pathogens in the control variants it was impossible to assess or confirm whether the tested products reduced the infestation with Fusarium sp.

Table 5. The influence of the applied preparations on selected chemical properties of maize seeds and stem and cob fusariosis.

\begin{tabular}{cccccccc}
\hline Variants & $\begin{array}{c}\text { N Content } \\
\mathbf{( \% )}\end{array}$ & $\begin{array}{c}\text { Protein } \\
\text { Content } \\
\mathbf{( \% )}\end{array}$ & $\begin{array}{c}\text { Starch } \\
\text { Content } \\
\mathbf{( \% )}\end{array}$ & $\begin{array}{c}\text { Ash Content } \\
\mathbf{( \% )}\end{array}$ & $\begin{array}{c}\text { Stem Rot } \\
\mathbf{( \% )}\end{array}$ & $\begin{array}{c}\text { Ear Hanging } \\
\mathbf{( \% )}\end{array}$ & $\begin{array}{c}\text { Ear Rot } \\
\mathbf{( \% )}\end{array}$ \\
\hline control & $1.41 \mathrm{a}$ & $8.84 \mathrm{a}$ & $69.2 \mathrm{c}$ & $1.25 \mathrm{ab}$ & $0.0 \mathrm{a}$ & $0.2 \mathrm{a}$ & $0.0 \mathrm{a}$ \\
BW & $1.42 \mathrm{a}$ & $8.87 \mathrm{a}$ & $70.5 \mathrm{abc}$ & $1.24 \mathrm{ab}$ & $0.0 \mathrm{a}$ & $0.3 \mathrm{a}$ & $0.0 \mathrm{a}$ \\
BWM & $1.42 \mathrm{a}$ & $8.96 \mathrm{a}$ & $71.6 \mathrm{a}$ & $1.18 \mathrm{~b}$ & $0.3 \mathrm{a}$ & $0.0 \mathrm{a}$ & $0.0 \mathrm{a}$ \\
BWE11 & $1.44 \mathrm{a}$ & $8.98 \mathrm{a}$ & $69.7 \mathrm{bc}$ & $1.27 \mathrm{a}$ & $0.0 \mathrm{a}$ & $0.2 \mathrm{a}$ & $0.0 \mathrm{a}$ \\
BWA & $1.42 \mathrm{a}$ & $8.85 \mathrm{a}$ & $70.5 \mathrm{abc}$ & $1.25 \mathrm{ab}$ & $0.3 \mathrm{a}$ & $0.0 \mathrm{a}$ & $0.0 \mathrm{a}$ \\
BWAE11 & $1.42 \mathrm{a}$ & $8.90 \mathrm{a}$ & $70.4 \mathrm{abc}$ & $1.24 \mathrm{ab}$ & $0.0 \mathrm{a}$ & $0.0 \mathrm{a}$ & $0.0 \mathrm{a}$ \\
BWAM & $1.38 \mathrm{a}$ & $8.63 \mathrm{a}$ & $71.2 \mathrm{ab}$ & $1.21 \mathrm{ab}$ & $0.0 \mathrm{a}$ & $0.0 \mathrm{a}$ & $0.0 \mathrm{a}$ \\
LSD (0.05) & $\mathrm{ns}$ & $\mathrm{ns}$ & 1.6 & 0.07 & $\mathrm{~ns}$ & $\mathrm{~ns}$ \\
\hline
\end{tabular}

Explanation: Means followed by the same letters do not differ significantly at $p \leq 0.05$; ns-insignificant; control—the control variant without fertilisers, BW—-biochar fertiliser, BWM—biochar fertiliser with mycorrhizal fungi, BWE11—biochar fertiliser with Bacillus bacteria, BWA - biochar fertiliser with algae, BWAE11—biochar fertiliser with algae and Bacillus sp. bacteria, BWAM—biochar fertiliser with algae and mycorrhizal fungi.

The individual frequency of distribution of discriminant scores across the first and second canonical variables, which together account for the total variation for the objects, clearly shows that the variants are differentiated across the two axes, suggesting clear boundaries for these variants (Figure 6A).

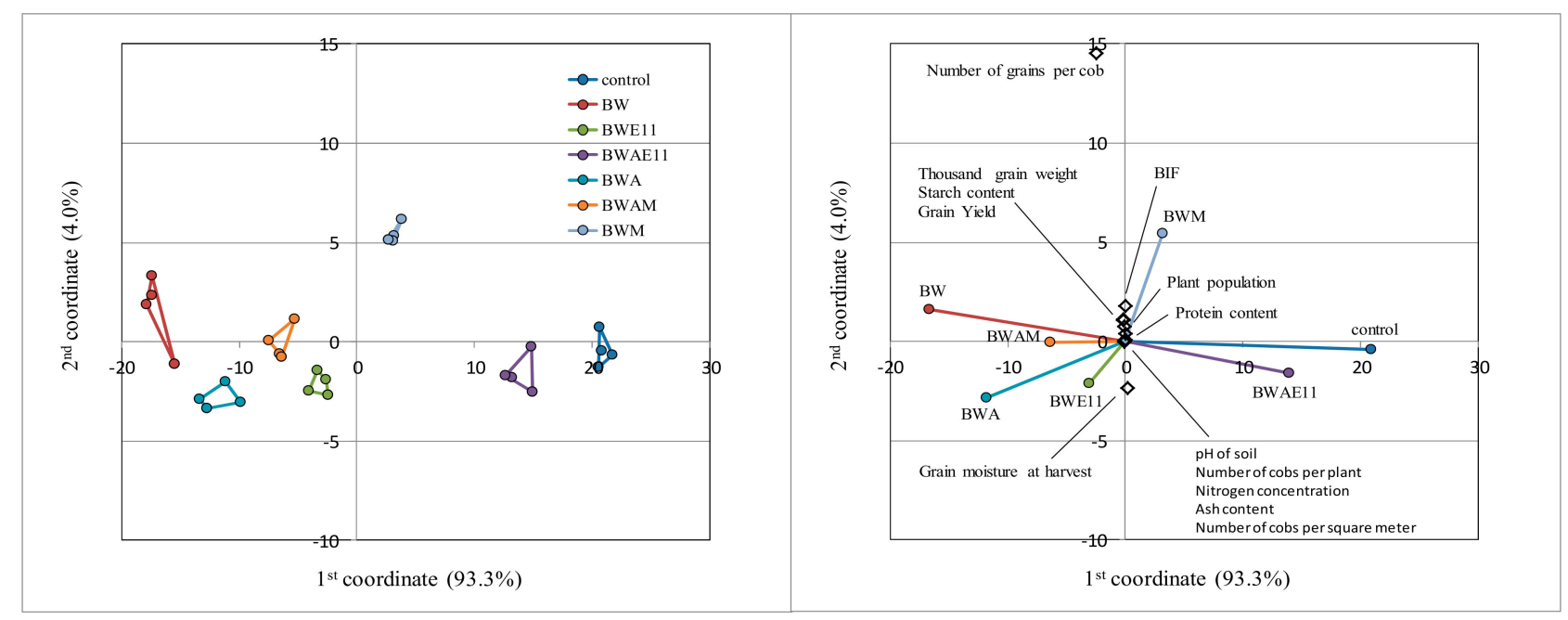

(A)

(B)

Figure 6. The canonical variate analysis showing the relationship between the experimental variants and the variables describing them ((A) — based on transformation by linear combination; (B) — based on singular value decomposition).

Canonical variate analysis (CVA) was used to estimate the cause-and-effect relationships between the parameters in the experimental variants. The CVA showed regularities between the dependent variables (BIF activity, soil $\mathrm{pH}$ value, plant density, number of maize seeds, and chemical composition of plants) and consisted of determining the components being a linear combination of these variables. The CVA enabled the identification of the variables which differentiated the experimental variants to the greatest extent. It was the type of variant that primarily differentiated the number of seeds per cob. The other factors whose values depended on the type of the experimental variant were: the seed moisture content at harvest, the enzymatic index of soil fertility-BIF, the thousand kernel weight, the starch content and the yield of seeds (Figure 6B). 
The analyses also revealed a negative correlation between the seed moisture content at harvest and the number of seeds per cob, the BIF value, thousand kernel weight, starch content, and yield of seeds. The soil $\mathrm{pH}$, the plant nitrogen content and the number of cobs differentiated the experimental variants to a very small extent. The soil $\mathrm{pH}$ exhibited a slight positive correlation with the soil enzymatic activity (BIF), thousand kernel weight, yield of seeds, and the number of seeds per cob. These dependencies were the most pronounced only in the BWM variant. The CVA also showed that the control variant and then the BW variant were the most different from the other variants in terms of all the tested parameters (Figure 6B).

\section{Conclusions}

The two-year study showed that the soil bacterial community was sensitive to the treatment with fertilisers based on lignocellulosic substrate and biochar as well as selected strains of microorganisms. All biofertiliser variants reduced the content of OTU sequences belonging to the Proteobacteria, Firmicutes, and Acidobacteria phylum in favour of the Actinobacteria phylum, which included numerous species capable of decomposing complex organic compounds and promoting plant growth.

There was a lower decrease in the soil $\mathrm{pH}$ in all biofertiliser variants than in the control variant.

The cultivation of maize lowered the soil $\mathrm{pH}$, which caused changes in the content and structure of the bacterial microbiome. The activity of soil enzymes (BIF) was also strongly correlated with the type of biofertiliser applied, and to some extent it was correlated with the soil $\mathrm{pH}$. The strongest $\mathrm{BIF}$ and soil $\mathrm{pH}$ reaction to the applied fertiliser was noted in the variant with arbuscular mycorrhizal fungi (BWM). The BWM product also had a positive effect on the plant moisture content at harvest, the yield and the starch content in seeds.

The study showed that the tested biofertilisers had a complex mode of action and their stimulation of microbial activity depended on the crop cultivation and soil conditions.

In order to work out a uniform position on the use of bio-fertiliser based on biochar and selected microorganisms in the conditions of Polish soils, its impact on the biological and chemical activity of the soil and the yield under other crops under different soil conditions should be examined. Taking into account the fact of the long-term use of fertilisers, it would be advisable to conduct further studies confirming the positive effect of the fertiliser on the soil structure and its other properties.

Nevertheless, the tested products, especially the BWM variant with mycorrhizal fungi of the Glomus sp. genus, are in line with the European Biodiversity Strategy of 20 May 2020.

Author Contributions: Conceptualisation, A.W.-M., A.N., T.P. and A.K.; methodology, A.W.-M., A.N., A.A.P., D.K. and T.P.; software, A.G., A.A.P.; formal analysis, A.W.-M., A.N. and T.P.; investigation, A.W.-M., A.N., T.P. and A.A.P., writing-original draft preparation, A.W.-M., A.N., T.P.; writingreview and editing, A.G. and A.K.; visualisation, A.W.-M. and D.K.; supervision, A.W.-M.; funding acquisition, A.K. All authors have read and agreed to the published version of the manuscript.

Funding: This research was funded by The European Regional Development Fund under Priority Axis 1 of the Regional Operational Program-Lubuskie 2020 ('Research on the Innovative Formula of Organic Fertilisers", RPLB.01.01.00-08-0047/16).

Institutional Review Board Statement: Not applicable.

Informed Consent Statement: Not applicable.

Data Availability Statement: All data collected during this experiment were deposited only in the date base of implemented project.

Conflicts of Interest: The authors declare no conflict of interest. 


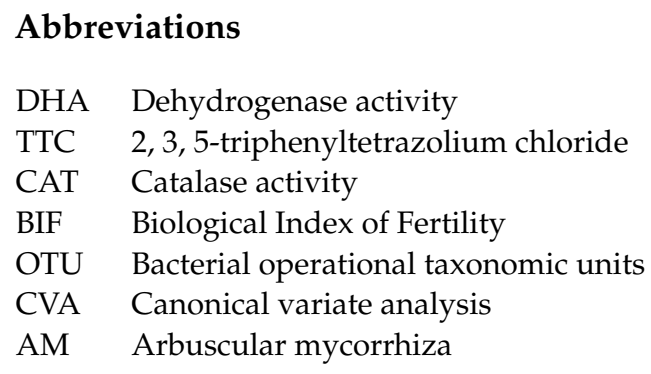

\section{References}

1. Davydov, R.; Sokolov, M.; Hogland, W.; Glinushkin, A.; Markaryan, A. The application of pesticides and mineral fertilizers in agriculture. In Proceedings of the EECE-2018, MATEC Web of Conferences, St. Petersburg, Russia, 19-20 November 2018; EDP Sciences: Les Ulis, France, 2018; p. 11003.

2. Zhong, W.; Gu, T.; Wang, W.; Zhang, B.; Lin, X.; Huang, Q.; Shen, W. The effects of mineral fertilizer and organic manure on soil microbial community and diversity. Plant Soil 2010, 326, 511-522. [CrossRef]

3. Geisseler, D.; Scow, K.M. Long-term effects of mineral fertilizers on soil microorganisms-A review. Soil Biol. Biochem. 2014, 75, 54-63. [CrossRef]

4. Alkharabsheh, H.M.; Seleiman, M.F.; Battaglia, M.L.; Shami, A.; Jalal, R.S.; Alhammad, B.A.; Almutairi, K.F.; Al-Saif, A.M. Biochar and its broad impacts in soil quality and fertility, nutrient leaching and crop productivity: A review. Agronomy 2021, 11, 993. [CrossRef]

5. Grzyb, A.; Wolna-Maruwka, A.; Niewiadomska, A. Environmental factors affecting the mineralization of crop residues. Agronomy 2020, 10, 1951. [CrossRef]

6. Butterly, C.R.; Baldock, J.A.; Tang, C. The contribution of crop residues to changes in soil ph under field conditions. Plant Soil 2013, 366, 185-198. [CrossRef]

7. Whalen, J.K. Managing soil biota-mediated decomposition and nutrient mineralization in sustainable agroecosystems. Adv. Agric. 2014, 2014, 1-13. [CrossRef]

8. Gorovtsov, A.V.; Minkina, T.M.; Mandzhieva, S.S.; Perelomov, L.V.; Soja, G.; Zamulina, I.V.; Rajput, V.D.; Sushkova, S.N.; Mohan, D.; Yao, J. The mechanisms of biochar interactions with microorganisms in soil. Environ. Geochem. Health 2019, 42, 1-24. [CrossRef]

9. Gul, S.; Whalen, J.K.; Thomas, B.W.; Sachdeva, V.; Deng, H. Physico-chemical properties and microbial responses in biocharamended soils: Mechanisms and future directions. Agric. Ecosys. Environ. 2015, 206, 46-59. [CrossRef]

10. Uchimiya, M.; Wartelle, L.H.; Klasson, K.T.; Fortier, C.A.; Lima, I.M. Influence of pyrolysis temperature on biochar property and function as a heavy metal sorbent in soil. J. Agric. Food Chem. 2011, 59, 2501-2510. [CrossRef]

11. Cao, X.; Harris, W. Properties of dairy-manure-derived biochar pertinent to its potential use in remediation. Bioresour. Technol. 2010, 101, 5222-5228. [CrossRef]

12. Quilliam, R.S.; Glanville, H.C.; Wade, S.C.; Jones, D.L. Life in the 'Charosphere'-Does biochar in agricultural soil provide a significant habitat for microorganisms? Soil Biol. Biochem. 2013, 65, 287-293. [CrossRef]

13. Man, Y.; Wang, B.; Wang, J.; Slanỳ, M.; Yan, H.; Li, P.; El-Naggar, A.; Shaheen, S.M.; Rinklebe, J.; Feng, X. Use of biochar to reduce mercury accumulation in Oryza sativa L: A trial for sustainable management of historically polluted farmlands. Environ. Int. 2021, 153, 106527. [CrossRef]

14. Blackwell, P.; Krull, E.; Butler, G.; Herbert, A.; Solaiman, Z. Effect of banded biochar on dryland wheat production and fertiliser use in south-western Australia: An agronomic and economic perspective. Soil Res. 2010, 48, 531-545. [CrossRef]

15. Palencia, P.; Martínez, F.; Pestana, M.; Oliveira, J.A.; Correia, P.J. Effect of Bacillus velezensis and Glomus intraradices on fruit quality and growth parameters in strawberry soilless growing system. J. Hortic. 2015, 84, 122-130. [CrossRef]

16. Chandanie, W.A.; Kubota, M.; Hyakumachi, M. Interactions between the arbuscular mycorrhizal fungus Glomus mosseae and plant growth-promoting fungi and their significance for enhancing plant growth and suppressing damping-off of cucumber (Cucumis sativus L.). Appl. Soil Ecol. 2009, 41, 336-341. [CrossRef]

17. Elsharkawy, M.M.; Shimizu, M.; Takahashi, H.; Hyakumachi, M. The plant growth-promoting fungus fusarium equiseti and the arbuscular mycorrhizal fungus Glomus mosseae induce systemic resistance against cucumber mosaic virus in cucumber plants. Plant Soil 2012, 361, 397-409. [CrossRef]

18. Colla, G.; Rouphael, Y.; Di Mattia, E.; El-Nakhel, C.; Cardarelli, M. Co-inoculation of Glomus intraradices and Trichoderma atroviride acts as a biostimulant to promote growth, yield and nutrient uptake of vegetable crops. J. Sci. Food Agric. 2015, 95, 1706-1715. [CrossRef]

19. Jemil, I.; Jridi, M.; Nasri, R.; Ktari, N.; Salem, R.B.S.-B.; Mehiri, M.; Hajji, M.; Nasri, M. Functional, antioxidant and antibacterial properties of protein hydrolysates prepared from fish meat fermented by Bacillus subtilis A26. Process Biochem. 2014, 49, 963-972. [CrossRef]

20. Lim, J.-H.; Kim, S.-D. Synergistic plant growth promotion by the indigenous auxins-producing PGPR Bacillus subtilis AH18 and Bacillus licheniforims K11. J. Korean Soc. Appl. Biol. Chem. 2009, 52, 531-538. [CrossRef] 
21. Grover, M.; Madhubala, R.; Ali, S.Z.; Yadav, S.K.; Venkateswarlu, B. Influence of Bacillus spp. strains on seedling growth and physiological parameters of sorghum under moisture stress conditions. J. Basic Microbiol. 2014, 54, 951-961. [CrossRef]

22. Jones, N.; Ray, B.; Ranjit, K.T.; Manna, A.C. Antibacterial activity of ZnO nanoparticle suspensions on a broad spectrum of microorganisms. FEMS Microbiol. Lett. 2008, 279, 71-76. [CrossRef] [PubMed]

23. Tate, J.J.; Gutierrez-Wing, M.T.; Rusch, K.A.; Benton, M.G. The Effects of plant growth substances and mixed cultures on growth and metabolite production of green algae Chlorella sp.: A review. J. Plant Growth Regul. 2013, 32, 417-428. [CrossRef]

24. Win, T.T.; Barone, G.D.; Secundo, F.; Fu, P. Algal Biofertilizers and plant growth stimulants for sustainable agriculture. Ind. Biotechnol. 2018, 14, 203-211. [CrossRef]

25. Bhagavathy, S.; Sumathi, P.; Bell, I.J.S. Green algae Chlorococcum humicola-A new source of bioactive compounds with antimicrobial activity. Asian Pac. J. Trop. Biomed. 2011, 1, S1-S7. [CrossRef]

26. Abu-Ghannam, N.; Rajauria, G. Antimicrobial activity of compounds isolated from algae. In Functional Ingredients from Algae for Foods and Nutraceuticals; Domínguez, H., Ed.; Woodhead Publishing: Cambridge, UK, 2013; pp. 287-306.

27. Ducey, T.F.; Novak, J.M.; Johnson, M.G. Effects of biochar blends on microbial community composition in two coastal plain soils. Agriculture 2015, 5, 1060-1075. [CrossRef]

28. Sheng, Y.; Zhu, L. Biochar alters microbial community and carbon sequestration potential across different soil pH. Sci. Total Environ. 2018, 622, 1391-1399. [CrossRef]

29. Cheng, H.; Wang, J.; Tu, C.; Lin, S.; Xing, D.; Hill, P.; Chadwick, D.; Jones, D.L. Arbuscular mycorrhizal fungi and biochar influence simazine decomposition and leaching. GCB Bioenergy 2021, 13, 708-718. [CrossRef]

30. Liu, L.; Li, J.; Yue, F.; Yan, X.; Wang, F.; Bloszies, S.; Wang, Y. Effects of arbuscular mycorrhizal inoculation and biochar amendment on maize growth, cadmium uptake and soil cadmium speciation in Cd-contaminated soil. Chemosphere 2018, 194, 495-503. [CrossRef]

31. Palanisamy, M.; Iniyakumar, M.; Elaiyaraju, P.; Uthandi, S.M.S.; Sivasubramanian, V. Effect of application of algal biochar on soil enzymes. J. Algal Biomass Util. 2017, 8, 1-9.

32. European Parliament. Communication from the Commission to the European Parliament, The Council, the European Economic and Social Committee and the Committee of the Regions EU-Biodiversity Strategy for 2030_Bringing Nature Back into Our Lives (COM/2020/380); European Parliament: Brussels, Belgium, 2020.

33. Camiña, F.; Trasar-Cepeda, C.; Gil-Sotres, F.; Leirós, C. Measurement of dehydrogenase activity in acid soils rich in organic matter. Soil Biol. Biochem. 1998, 30, 1005-1011. [CrossRef]

34. Rodríguez-Kábana, R.; Truelove, B. Effects of crop rotation and fertilization on catalase activity in a soil of the southeastern United States. Plant Soil 1982, 69, 97-104. [CrossRef]

35. Stefanic, G.; Eliade, G.; Chirnogeanu, I. Researches concerning a biological index of soil fertility. In Proceedings of the 5. Symposium on Soil Biology, Jassy, Romania, 17 February 1981.

36. EPPO. Fusarium Ear Rot of Maize. EPPO Bull. 2015, 45, 336-339. [CrossRef]

37. Commission Regulation (EC) No 152/2009 of 27 January 2009 laying down the methods of sampling and analysis for the official control of feed. Off. J. Eur. Union I 2009, 54, 1-130.

38. Callahan, B.J.; McMurdie, P.J.; Rosen, M.J.; Han, A.W.; Johnson, A.J.A.; Holmes, S.P. DADA2: High-resolution sample inference from illumina amplicon data. Nat. Methods 2016, 13, 581-583. [CrossRef]

39. R Core Team. R: A Language and Environment for Statistical Computing; R Foundation for Statistical Computing: Vienna, Austria, 2016.

40. Murali, A.; Bhargava, A.; Wright, E.S. IDTAXA: A novel approach for accurate taxonomic classification of microbiome sequences. Microbiome 2018, 6, 140. [CrossRef]

41. McMurdie, P.J.; Holmes, S. Phyloseq: An $\mathrm{r}$ package for reproducible interactive analysis and graphics of microbiome census data. PLoS ONE 2013, 8, e61217. [CrossRef]

42. Rognes, T.; Flouri, T.; Nichols, B.; Quince, C.; Mahé, F. VSEARCH: A versatile open source tool for metagenomics. PeerJ 2016, 4, e2584. [CrossRef]

43. Větrovský, T.; Baldrian, P.; Morais, D. SEED 2: A user-friendly platform for amplicon high-throughput sequencing data analyses. Bioinformatics 2018, 34, 2292-2294. [CrossRef]

44. Kayzer, D. A Note on testing hypotheses concerning interaction with special reference to a graphical presentation in the space of canonical variates. Biom. Lett. 2019, 56, 89-104. [CrossRef]

45. Kayzer, D.; Frankowski, P.; Zbierska, J.; Staniszewski, R. Evaluation of trophic parameters in newly built reservoir using canonical variates analysis. In Proceedings of the XLVIII Seminar of Applied Mathematics, Boguszów-Gorce, Poland, 9-11 September 2018; Volume 23, p. 00019.

46. Staniszewski, R.; Frankowski, P.; Kayzer, D.; Zbierska, J.; Achtenberg, K. Reconstruction of ancient lake after peat excavationA case study about water quality. Appl. Sci. 2021, 11, 4213. [CrossRef]

47. Campbell, N.A.; Atchley, W.R. The geometry of canonical variate analysis. Syst. Biol. 1981, 30, 268-280. [CrossRef]

48. Lejeune, M.; Caliński, T. Canonical analysis applied to multivariate analysis of variance. J. Multivar. Anal. 2000, 72, 100-119. [CrossRef]

49. Kayzer, D.; Borowiak, K.; Budka, A.; Zbierska, J. Study of interaction in bioindication research on tobacco plant injuries caused by ground level ozone. Environmetrics 2009, 20, 666-675. [CrossRef] 
50. Furtak, K.; Grządziel, J.; Gałązka, A.; Niedźwiecki, J. Prevalence of unclassified bacteria in the soil bacterial community from floodplain meadows (fluvisols) under simulated flood conditions revealed by a metataxonomic approachss. Catena 2020, 188, 104448. [CrossRef]

51. Mhuantong, W.; Wongwilaiwalin, S.; Laothanachareon, T.; Eurwilaichitr, L.; Tangphatsornruang, S.; Boonchayaanant, B.; Limpiyakorn, T.; Pattaragulwanit, K.; Punmatharith, T.; McEvoy, J. Survey of microbial diversity in flood areas during Thailand 2011 Flood Crisis using high-throughput tagged amplicon pyrosequencing. PLoS ONE 2015, 10, e0128043. [CrossRef] [PubMed]

52. Delgado-Baquerizo, M. Obscure soil microbes and where to find them. ISME 2019, 13, 2120-2124. [CrossRef] [PubMed]

53. Breidenbach, B.; Brenzinger, K.; Brandt, F.B.; Blaser, M.B.; Conrad, R. The effect of crop rotation between wetland rice and upland maize on the microbial communities associated with roots. Plant Soil 2017, 419, 435-445. [CrossRef]

54. Francioli, D.; Schulz, E.; Lentendu, G.; Wubet, T.; Buscot, F.; Reitz, T. Mineral vs. organic amendments: Microbial community structure, activity and abundance of agriculturally relevant microbes are driven by long-term fertilization strategies. Front. Microbiol. 2016, 7, 1446. [CrossRef]

55. Mori, K.; Yamaguchi, K.; Sakiyama, Y.; Urabe, T.; Suzuki, K. Caldisericum exile gen. nov., sp. nov., an anaerobic, thermophilic, filamentous bacterium of a novel bacterial phylum, Caldiserica phyl. nov., originally called the Candidate phylum op5, and description of Caldisericaceae fam. nov., Caldisericales ord. nov. and Caldisericia classis nov. Int. J. Syst. Evol. Microbiol. 2009, 59, 2894-2898.

56. Poddar, N.; Badilla, C.; Maghool, S.; Osborne, T.H.; Santini, J.M.; Maher, M.J. Structural and functional investigation of the periplasmic arsenate-binding protein arrx from Chrysiogenes arsenatis. Biochemistry 2021, 60, 465-476. [CrossRef]

57. Abdul Rahman, N.; Parks, D.H.; Vanwonterghem, I.; Morrison, M.; Tyson, G.W.; Hugenholtz, P. A Phylogenomic analysis of the bacterial phylum Fibrobacteres. Front. Microbiol. 2016, 6, 1469. [CrossRef]

58. De Paula Silveira Mello, L.; dos Santos, A.C.; dos Santos, R.M.; Kandasamy, S.; Lazarovits, G.; Rigobelo, E.C. Application of the bacterial strains Ruminobacter amylophilus, Fibrobacter succinogenes and Enterococcus faecium for growth promotion in maize and soybean plants. Aust. J. Crop Sci. 2020, 14, 2020-2027. [CrossRef]

59. Sharma, M.; Mishra, V.; Rau, N.; Sharma, R.S. Increased iron-stress resilience of maize through inoculation of siderophoreproducing Arthrobacter globiformis from mine. J. Basic Microbiol. 2016, 56, 719-735. [CrossRef]

60. Yadav, A.N.; Verma, P.; Kumar, S.; Kumar, V.; Kumar, M.; Sugitha, T.C.K.; Singh, B.P.; Saxena, A.K.; Dhaliwal, H.S. Actinobacteria from rhizosphere: Molecular diversity, distributions, and potential biotechnological applications. In New and Future Developments in Microbial Biotechnology and Bioengineering; Gupta, K., Ed.; Elsevier: Amsterdam, The Netherlands, 2016 ; pp. 13-41.

61. Baudoin, E.; Benizri, E.; Guckert, A. Impact of artificial root exudates on the bacterial community structure in bulk soil and maize rhizosphere. Soil Biol. Biochem. 2003, 35, 1183-1192. [CrossRef]

62. Wolna-Maruwka, A.; Niewiadomska, A.; Klama, J. Biological activity of grey-brown podzolic soil organically fertilized for maize cultivation in monoculture. Pol. J. Environ. Stud. 2009, 18, 931-939.

63. Tian, J.; Wang, J.; Dippold, M.; Gao, Y.; Blagodatskaya, E.; Kuzyakov, Y. Biochar affects soil organic matter cycling and microbial functions but does not alter microbial community structure in a paddy soil. Sci. Total Environ. 2016, 556, 89-97. [CrossRef]

64. Elzobair, K.A.; Stromberger, M.E.; Ippolito, J.A.; Lentz, R.D. Contrasting effects of biochar versus manure on soil microbial communities and enzyme activities in an aridisol. Chemosphere 2016, 142, 145-152. [CrossRef]

65. Chen, J.; Li, S.; Liang, C.; Xu, Q.; Li, Y.; Qin, H.; Fuhrmann, J.J. Response of microbial community structure and function to short-term biochar amendment in an intensively managed bamboo (Phyllostachys praecox) plantation soil: Effect of particle size and addition rate. Sci. Total Environ. 2017, 574, 24-33. [CrossRef]

66. Li, G.L.; Zhou, C.H.; Fiore, S.; Yu, W.H. Interactions between microorganisms and clay minerals: New insights and broader applications. Appl. Clay Sci. 2019, 177, 91-113. [CrossRef]

67. Gryndler, M. Interactions of arbuscular mycorrhizal fungi with other soil organisms. In Arbuscular mycorrhizas: Physiology and Function; Koltai, H., Kapulnik, Y., Eds.; Springer: Berlin/Heidelberg, Germany, 2000; pp. 239-262.

68. Rangel-Castro, J.I.; Danell, E.; Pfeffer, P.E. A 13C-NMR study of exudation and storage of carbohydrates and amino acids in the ectomycorrhizal edible mushroom Cantharellus cibarius. Mycologia 2002, 94, 190-199.

69. Landeweert, R.; Hoffland, E.; Finlay, R.D.; Kuyper, T.W.; van Breemen, N. Linking plants to rocks: Ectomycorrhizal fungi mobilize nutrients from minerals. Trends Ecol. Evol. 2001, 16, 248-254. [CrossRef]

70. Olsson, P.A.; Chalot, M.; Baath, E.; Finlay, R.D.; Söderström, B. Ectomycorrhizal mycelia reduce bacterial activity in a sandy soil. FEMS Microbiol. Ecol. 1996, 21, 77-86. [CrossRef]

71. Rillig, M.C. Arbuscular mycorrhizae and terrestrial ecosystem processes. Ecol. Lett. 2004, 7, 740-754. [CrossRef]

72. Guangming, L.; Xuechen, Z.; Xiuping, W.; Hongbo, S.; Jingsong, Y.; Xiangping, W. Soil Enzymes as indicators of saline soil fertility under various soil amendments. Agric. Ecosyst. Environ. 2017, 237, 274-279. [CrossRef]

73. Joergensen, R.G.; Wichern, F. Alive and kicking: Why dormant soil microorganisms matter. Soil Biol. Biochem. 2018, 116, 419-430. [CrossRef]

74. Vázquez, M.M.; César, S.; Azcón, R.; Barea, J.M. Interactions between arbuscular mycorrhizal fungi and other microbial inoculants (Azospirillum, Pseudomonas, Trichoderma) and their effects on microbial population and enzyme activities in the rhizosphere of maize plants. Appl. Soil Ecol. 2000, 15, 261-272. [CrossRef] 
75. Wolna-Maruwka, A.; Piechota, T.; Dach, J.; Szczech, M.; Szczerbal, I.; Niewiadomska, A.; Budka, A.; Gaj, R. The Influence of Trichoderma on the phytosanitary status of soil and yield of red beets (Beta vulgaris L. subsp. vulgaris). Pol. J. Environ. Stud. 2017, 26, 847-859. [CrossRef]

76. Niewiadomska, A.; Sulewska, H.; Wolna-Maruwka, A.; Klama, J. Effect of organic fertilization on development of proteolytic bacteria and activity of proteases in the soil for cultivation of maize (Zea mays L.). Arch. Environ. Prot. 2010, 36, 47-56.

77. Hupe, A.; Schulz, H.; Bruns, C.; Haase, T.; Heß, J.; Joergensen, R.G.; Wichern, F. Even Flow? Changes of carbon and nitrogen release from pea roots over time. Plant Soil 2018, 431, 143-157. [CrossRef]

78. Pińskwar, I.; Choryński, A.; Kundzewicz, Z.W. Severe drought in the spring of 2020 in Poland-More of the same? Agronomy 2020, 10, 1646. [CrossRef]

79. Tomczyk, A.M.; Bednorz, E. The Extreme Year-Analysis of thermal conditions in Poland in 2018. Theor. Appl. Climatol. 2020, 139, 251-260. [CrossRef]

80. Jalal, F.; Arif, M.; Akhtar, K.; Khan, A.; Naz, M.; Said, F.; Zaheer, S.; Hussain, S.; Imtiaz, M.; Khan, M.A. Biochar integration with legume crops in summer gape synergizes nitrogen use efficiency and enhance maize yield. Agronomy 2020, 10, 58. [CrossRef]

81. Guo, M. The 3R principles for applying biochar to improve soil health. Soil Systems 2020, 4, 9. [CrossRef]

82. Hu, Y.; Xie, W.; Chen, B. Arbuscular mycorrhiza improved drought tolerance of maize seedlings by altering Photosystem II efficiency and the levels of key metabolites. Chem. Biol. Technol. Agric. 2020, 7, 1-14. [CrossRef]

83. Nyamwange, M.M.; Njeru, E.M.; Mucheru-Muna, M.; Ngetich, F. Soil management practices affect arbuscular mycorrhizal fungi propagules, root colonization and growth of rainfed maize. AIMS Agric. Food 2018, 3, 120-134. [CrossRef]

84. Moitzi, G.; Thünauer, G.; Gronauer, A. Energy use and energy efficiency of corn production with different mineral fertilization in south Styria. In Proceedings of the International Conferenceof Agricultural Engineering, Zurich, Switzerland, 6-10 July 2014.

85. Pfordt, A.; Ramos Romero, L.; Schiwek, S.; Karlovsky, P.; von Tiedemann, A. Impact of environmental conditions and agronomic practices on the prevalence of fusarium species associated with ear-and stalk rot in maize. Pathogens 2020, 9, 236. [CrossRef] [PubMed] 